\title{
CLIMATIC AND PHYSIOGRAPHIC CONTROLS ON WETLAND TYPE AND DISTRIBUTION IN MANITOBA, CANADA
}

\author{
Linda Halsey ${ }^{* *}$, Dale Vitt', and Stephen Zoltai² \\ ' Devonian Botanic Garden and Department of Biological Sciences \\ University of Alberta \\ Edmonton, Alberta, Canada T6E 2 Gl \\ 2 Canadian Forest Service \\ Northern Forestry Centre \\ 5320-122 St. \\ Edmonton, Alberta, Canada T6G $3 S 5$
}

\begin{abstract}
Wetlands represent a substantial part of Manitoba's terrestrial landscape, covering $233,340 \mathrm{~km}^{2}$ or $43 \%$ of the province; peatlands represent $90 \%$ of all wetlands. A wetland inventory for Manitoba is presented following a classification scheme grounded in wetland function, vegetation, and landform. The province is subdivided into twelve wetland regions each having distinctive wetland types and abundances. A hybrid Detrended Canonical Correspondance Analysis (DCCA) indicates that wetland distribution in the province is largely controlled by allogenic factors of climate and physiography. The first canonical axis represents the variance in wetland distribution occurring along a north-to-south gradient within the province. In northern Manitoba, permafrost bogs dominate, replaced southwards by bogs without permafrost and fens with and without internal lawns. Farther south, peatlands are replaced by non-peat-accumulating wetlands. This wetland distributional gradient is most strongly correlated to mean annual temperature, with thermal seasonal aridity, annual precipitation, and moisture deficit (precipitation-potential evaporation) also significant. Significant allogenic variables correlated to the first canonical axis are not restricted to climate alone. The type of bedrock geology in the area also plays an important role in determining wetland distribution, with bogs occurring preferentially in areas of acidic bedrock, while fens are found on calcareous bedrock. The second canonical axis represents a surface-water flow gradient, with patterned fens and marshes having relatively large amounts of surface-water flow on one end and nonpermafrost bogs and swamps with low amounts of surface-water flow on the other. Texture of the subsurface is the most important variable explaining the second axis, with sediments having high hydraulic conductivity correlated to wetlands with high surface-water flow, while sediments with low hydraulic conductivity are related to wetlands with low surfacewater flow. Annual precipitation is also a statistically significant variable explaining the variance in wetland distribution along the second axis.
\end{abstract}

Key Words: wetlands, peatlands, mires, permafrost, land classification, remote sensing, Manitoba

\section{INTRODUCTION}

Wetlands are a vital part of northern landscapes and have a broad range of unique and diverse geomorphic/ biological systems that create complex patterns at various scales, both spatially and temporally. The environmental processes that control wetland development form hydrologic, chemical, and biotic gradients and commonly have strong cross-correlations (Zoltai and Vitt 1995). These interrelated gradients are here divided into five nodes that define the wetland classes used in Canada, of which three classes are non-peat-forming

\footnotetext{
* Correspondence author; email: lhalsey@gpu.srv.ualberta.ca.
}

wetlands (generally having $<40 \mathrm{~cm}$ of accumulated organics) and two classes are peatlands (wetlands having $>40 \mathrm{~cm}$ of accumulated organics). Following the National Wetland Working Group (NWWG 1988), non-peat-forming wetlands are subdivided into 1) shallow open waters, 2) marshes, and 3) swamps, whereas peatlands can be subdivided as 1) fens and 2) bogs.

Shallow open waters are non-peat-forming wetlands that are characterized by aquatic processes generally confined to less than $2 \mathrm{~m}$ depth at midsummer. Marshes are open, non-peat-forming wetlands dominated by sedges (Cyperaceae) and other monocots and are characterized by large seasonal water-level fluctuations, 
relatively large amounts of water flow, and influence from ground- and/or surface-waters. Swamps are forested, wooded, or shrubby systems where tree growth is limited by regional climatic conditions and/or seasonally wet conditions. Both marshes and swamps have abundant vascular plant production; however, peat accumulation is limited by high decomposition rates. Non-peat-accumulating wetlands have a poorly developed bryophyte layer associated with relatively high seasonal water-level fluctuations and high vascular plant production.

Peatlands differ from non-peat-forming wetlands by a combination of interrelated hydrologic, chemical, and biotic factors that result in a decrease in decomposition relative to plant production allowing for the accumulation of peat. The stabilization of seasonal water levels and restriction of water flow through a wetland allows the establishment and development of a bryophyte layer. Peatlands can be subdivided hydrologically into fens that are geogenous systems affected by mineral soil waters (ground and/or surface) that may or may not be rich in mineral elements, and bogs that are ombrogenous, receiving their surface-water only from precipitation. Comparing the surface-water temperatures of bogs and fens, bogs have the lowest temperatures (Vitt et al. 1995), as a result of minimal water flow, relatively low water table, greater insulating capacity, and low thermal conductivity of the relatively dry Sphagnum-rich, organic layer. Permafrost, consequently, is generally restricted to bogs at its southern limit, where it forms peat plateaus, palsas, and bogs with intermittent permafrost (Vitt et al. 1994), with the percent of permafrost cover correlated to mean annual temperature (Halsey et al. 1995).

The spatial distribution of wetlands indicates that climatic parameters are the dominant factors influencing the development and differentiation of wetland types (Damman 1979, Glaser and Janssens 1986, Vitt et al. 1996), with physiographic controls such as substrate texture and topography also being important (Almquist-Jacobson and Foster 1995, Vitt et al. 1996). In general, non-peat-accumulating wetlands are found south of peatlands and are replaced both spatially and temporally when a climatic threshold is reached (Kuhry et al. 1993) This climatic threshold has been defined for localized areas as where precipitation exceeds evaporation, mean annual precipitation values are $>500 \mathrm{~mm}$, and biotemperatures are less than 24 (Gignac and Vitt 1994).

Although wetland ecosystems represent a large portion of the northern hemisphere, studies examining the relationships between wetland type and such largescale allogenic factors as climate and physiography have been limited due largely to a lack of detailed wetland inventories. Studies that have been conducted
Table 1. Wetland classification system.

\begin{tabular}{|c|c|c|}
\hline Classification Level & Attributes & Code \\
\hline \multirow[t]{5}{*}{ Wetland Class } & Bog & B \\
\hline & Fen & $\mathrm{F}$ \\
\hline & Marsh & M \\
\hline & Swamp & $S$ \\
\hline & Shallow Open Water & W \\
\hline \multirow{3}{*}{ Vegetation Modifier } & Forested $(>70 \%$ tree cover $)$ & $\mathrm{F}$ \\
\hline & Wooded $(>6 \%-70 \%$ tree cover $)$ & $\mathrm{T}$ \\
\hline & Open $(\leq 6 \%$ tree cover $)$ & $\mathrm{O}$ \\
\hline Wetland Landform & Patterned & $\mathrm{P}$ \\
\hline \multirow[t]{3}{*}{ Modifier } & Permafrost & $\mathrm{X}$ \\
\hline & Type 2 internal lawns & I \\
\hline & Nonpatterned & $\mathrm{N}$ \\
\hline
\end{tabular}

have been largely qualitative (i.e., Damman 1979, Gore 1983, Crum 1988, Glaser 1992) or examine one aspect of distribution, such as the peatland limit (i.e., Gignac and Vitt 1994). The objectives of this study were to 1) examine the distribution of wetlands over a large area, here the Province of Manitoba, Canada, in order to determine trends in wetland distribution and 2) elucidate how allogenic factors control wetland type and distribution using a quantified data set.

\section{METHODS}

\section{Mapping and Classification}

Wetlands and wetland complexes were classified from $1: 40,000$ to $1: 60,000$ aerial photographs and transferred to $1: 250,000$ base maps. Wetlands were classified using a hierarchical wetland classification that includes three levels: 1) wetland class (function), 2 ) vegetation modifier, and 3 ) wetland landform modifier (Table 1). At the scale of mapping used here, individual wetlands were rarely identified, with most polygons being composed of wetland complexes with components identified to the nearest $10 \%$ cover.

\section{Wetland Distribution Summaries}

Wetland complex maps created at 1:250,000 scale for the province were subdivided into $0.25^{\circ}$ latitude and $0.5^{\circ}$ longitude grids. Extent of each wetland by type was than calculated for each grid using the raster method. Raster block size was $0.5 \mathrm{~cm}^{2}$ (equivalent to $\left.1.6525 \mathrm{~km}^{2}\right)$. Gridded wetland abundance data were contoured using Macgridzo (Rockware 1991). Grid centroids were assembled into nationally recognized ecodistricts (Ecological Stratification Working Group 1995), representing areas of relatively homogeneous physical landscape and climatic conditions (Veldhuis et al. 1996). The extent of each wetland type was de- 


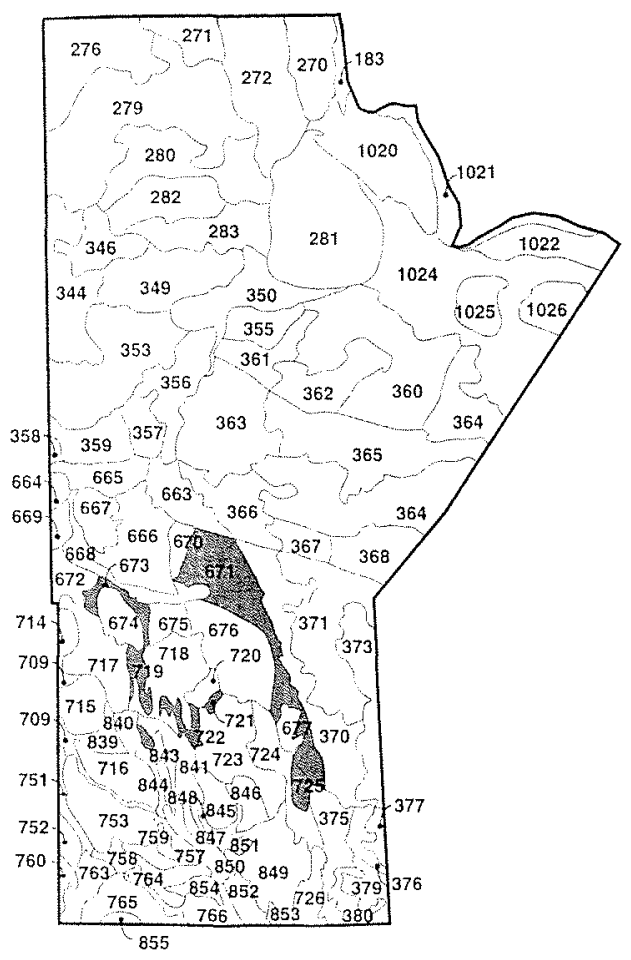

Figure 1. Ecodistricts of Manitoba. Ecodistrict numbers are not sequential as they represent a subset of a larger national database (Ecological Stratification Working Group 1995).

termined for each of the terrestrial landscape ecodistricts (Figure 1) within Manitoba.

\section{Allogenic Data}

Climatic and physiographic data were assembled for each ecodistrict from a number of sources. Mean annual temperatures and thermal aridity indices (TSAI) (total yearly precipitation/average mean May to October temperatures) were generated by a linear model using all available climate stations, excluding cities, for the period 1951-1980 (Environment Canada 1982) as well as location and elevation following the method of Halsey et al. (1995). For mean annual temperature, $\mathrm{r}^{2}=0.961$, while for TSAI, $\mathrm{r}^{2}=0.720$. Climate values were generated using these models for each $0.25^{\circ}$ latitude and $0.5^{\circ}$ longitude grid and contoured using Macgridzo (Rockware 1991) (Figure 2). Ecodistrict values for mean annual temperature and TSAI were calculated from the mean grid values. Other climatic parameters were taken from Veldhuis et al. (1996) and included number of frost free days, total annual precipitation, growing degree days $>5^{\circ} \mathrm{C}$, and moisture deficit (precipitation-potential evapotransporation) (Figure 3).

Physiographic parameters gathered included dominant topography, mineral soil texture, and bedrock geology for each of the terrestrial landscape ecodistricts
A

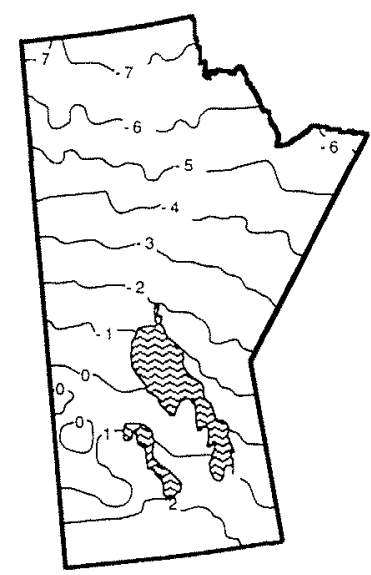

B

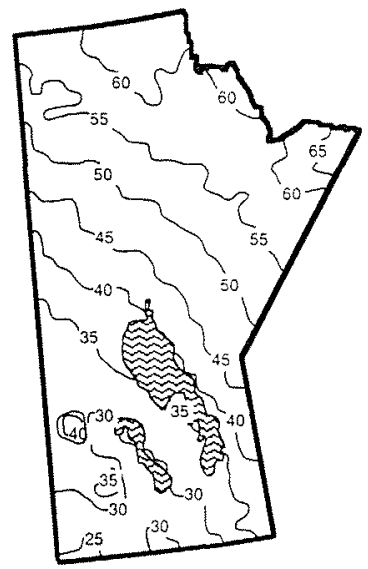

Figure 2. Contour maps of climatic allogenic variables: A) mean annual temperature, B) thermal seasonal aridity index.

(Figure 4). Topography and mineral soil texture were determined for each ecodistrict from available data (Dredge et al. 1986, Klassen 1986, Dredge and Nixon 1992, Velduis et al. 1996), while bedrock geology was taken from Manitoba Mineral Division (1994). Topography was coded on a three-point scale, with level topography receiving a value of 1 and hummocky topography coded as 3 . Mineral soil texture was subdivided into a six-point scale, with sediment of low hydraulic conductivity (clay) receiving a value of 1 and sediment of high hydraulic conductivity (sand and gravel) receiving 6. Bedrock was classified by age, with Precambrian rocks receiving the lowest score.

\section{Statistical Analyses}

Ecodistricts were classified by wetland type and abundance using TWINSPAN (Hill 1979), a two-way indicator analysis that produces a hierarchical classification of both ecodistrict and wetland type. TWINSPAN creates clusters based on user-supplied wetland abundance cut-levels. In this study, we used cut-levels of $0,1,5,10$, and $25 \%$. Misclassified ecodistricts and those identified by TWINSPAN as being borderline to a TWINSPAN group where placed into the ecologically most meaningful group as identified by the wetland types and abundances.

Detrended Correspondence Analysis (DCA) was used to ordinate the wetland distributional data. A DCA was chosen to remove any relationships between higher and lower axes, and for all wetland distributional data to have equal distances on the ordination (Gauch 1982). A Detrended Canonical Correspondence Analysis (DCCA) was then used to relate the climatic and physiographic variables to the DCA ordination axes generated from the wetland distributional 


\section{A}
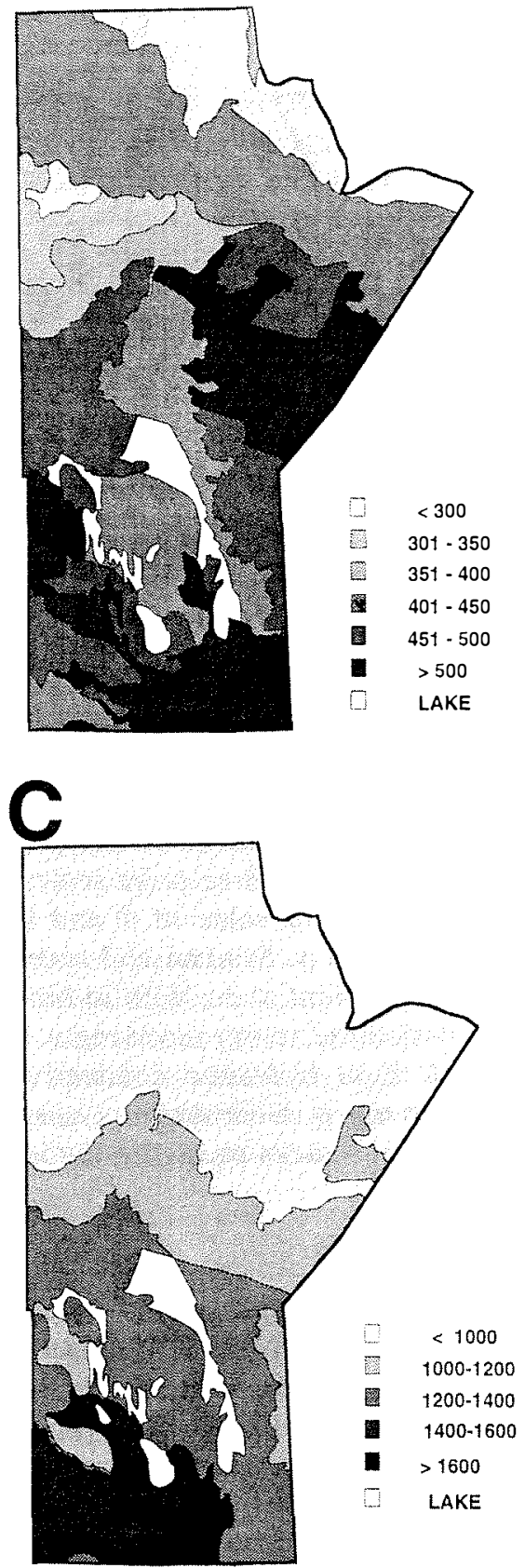

B

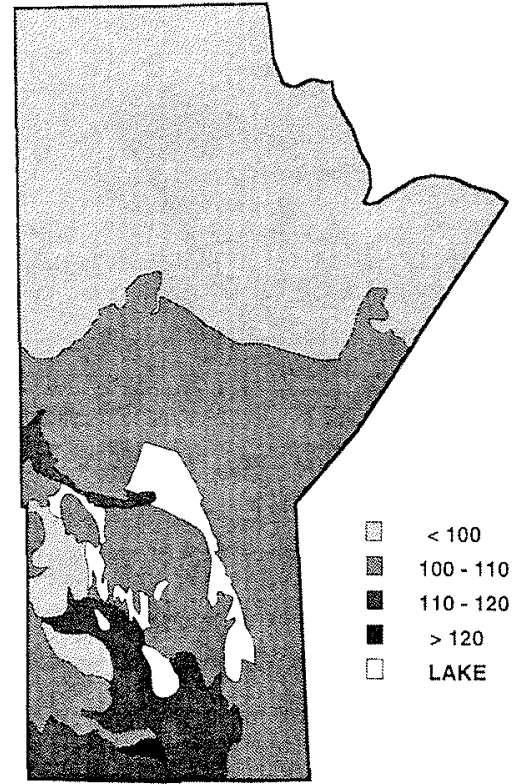

D

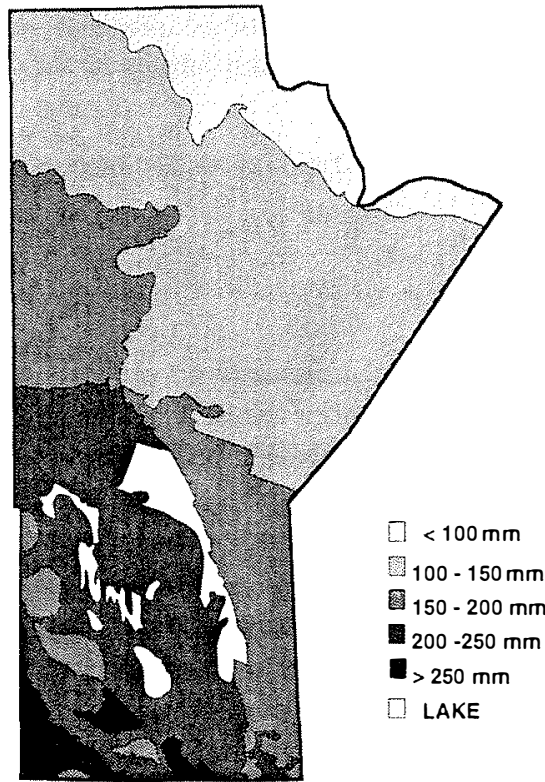

Figure 3. Ecodistrict maps of climatic allogenic variables: A) total yearly precipitation, B) number of frost free days, C) growing degree days $>5^{\circ} \mathrm{C}$, D) moisture deficit.

data. The hybrid DCA/DCCA was implemented in the computer program CANOCO 3.1 (ter Braak 1988, 1991).

\section{RESULTS AND DISCUSSION}

Wetland Types and Distributions

Bogs. Bogs develop in areas of restricted surface-water flow and are found along drainage divides, in stagna- tion zones within peatland complexes created in association with surface-water-flow obstructions, and in small, restricted basins. In Manitoba, bogs are found north of the southern limit of Picea mariana (Moench) Voss (Zoltai 1975), corresponding to the southern limit of the boreal forest (Hogg 1994) (Figure 5a). Bogs are subdivided into forms based on tree cover, with open bogs having $\leq 6 \%$ cover (excluding areas that have recently burned), wooded bogs having $>6$ to $70 \%$ 

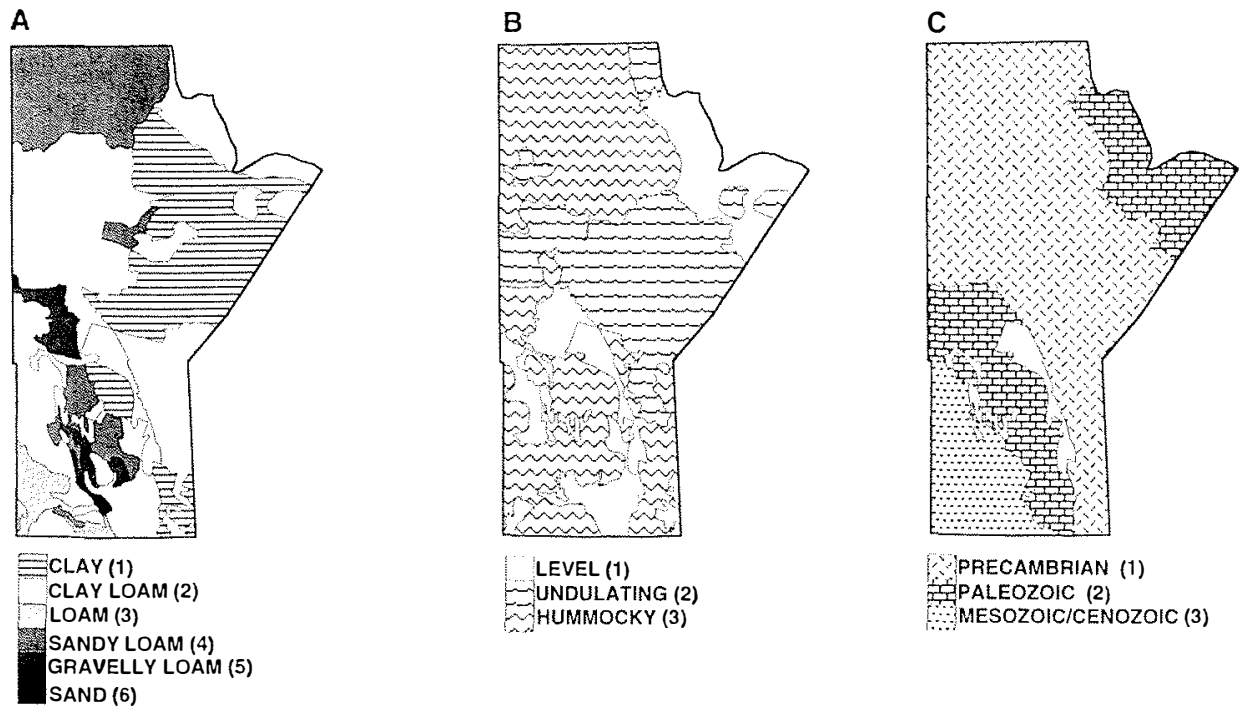

Figure 4. Ecodistrict maps of physiographic allogenic variables: A) topography, B) mineral soil texture. C) bedrock geology.

A

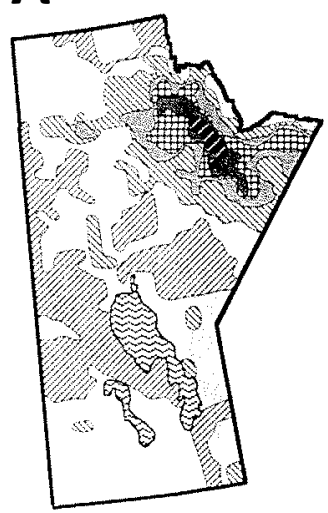

C

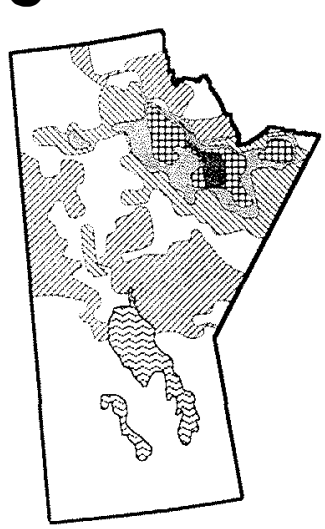

B
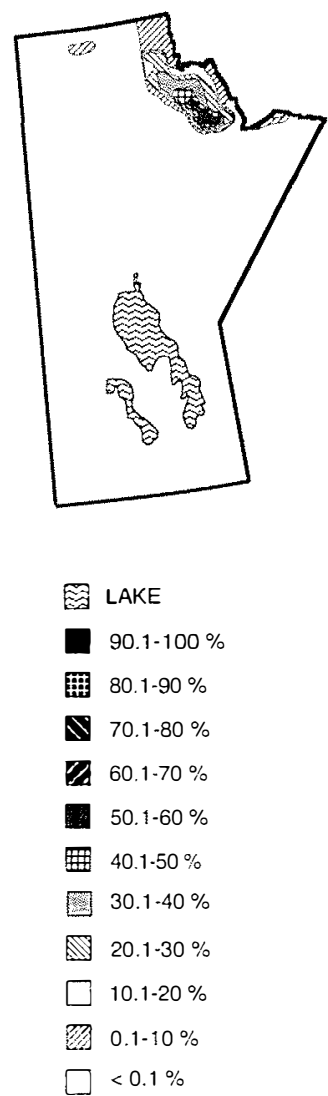

Figure 5. Contoured wetland distribution maps. Legend for $\%$ cover of all maps is at lower right. A) distribution of all bog landforms in Manitoba, ---contour interval is $10 \%$; B) distribution of Open Permafrost Bogs With or Without Collapse Scars, --contour interval is $10 \%$; C) distribution of Wooded-to-Forested Permafrost Bogs (peat plateaus) With or Without Collapse Scars, -contour interval is $10 \%$.

cover, and forested bogs having $>70 \%$ cover. In Manitoba, bogs are forested exclusively with Picea mariana (Vitt et al. 1994). The presence of permafrost and internal lawns is also used in subdividing bogs following Vitt et al. (1994). Following these criteria, five bog forms can be recognized.

Open Permafrost Bogs With or Without Collapse Scars (BOX). Open Permafrost Bogs are virtually treeless with only scattered individuals of Picea mariana existing as wind-blasted krumholz. They may contain circular-to-irregularly shaped collapse scars that have a sharp boundary with the surrounding permafrost bog (Figure 6a). These bogs are permafrost-dominated, with no permafrost in the collapse scars. Ground cover on Open Permafrost Bogs is dominated by lichens, including species of Cladonia, Cetraria s.l., and Cladina interspersed with patches of Sphagnum fuscum (Schimp.) Klinggr. Collapse scars have surfaces approximately $100 \mathrm{~cm}$ below the permafrost bog surface and have ground cover dominated by Carex and carpet species of Sphagnum. Permafrost bogs are characterized by polygonal patterning on the surface, reflecting the presence of ice wedges beneath the ground, and are associated with small-to-large, quasi-circular thaw lakes that are underlain by permafrost. Open Permafrost Bogs are restricted to northeastern Manitoba and concentrated to the west of the Hudson Bay coast (Figure $5 b)$.

Wooded-to-Forested Permafrost Bogs (peat plateaus) With or Without Collapse Scars (BTX). Wooded-to-Forested Permafrost Bogs have a relatively flat, raised surface that is dominated by a ground layer of lichens, sometimes interspersed with Pleurozium schreberi (Brid.) Mitt, Sphagnum fuscum, S. capilli- 

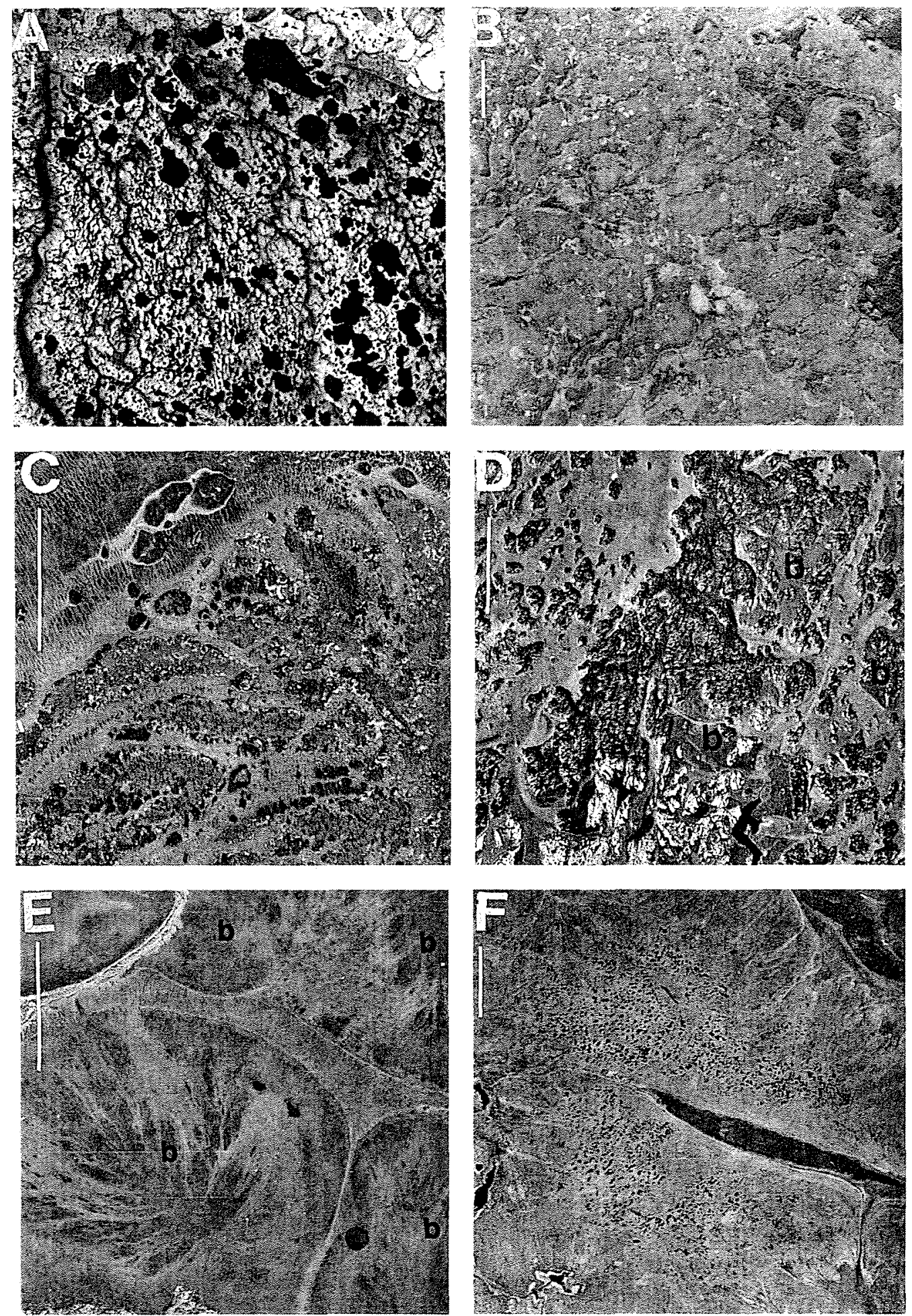

Figure 6. Aerial photographs of bog landforms in Manitoba. Scale bars represent $1 \mathrm{~km}$. A) Open Permafrost Bog (BOX) with characteristic polygonal patterning on the surface. Quasi-circular thaw lakes (WON) are associated with this landform-from Hudson Bay Lowland (58 $06^{\prime} \mathrm{N}$ and $\left.94^{\circ} 07^{\prime} \mathrm{W}\right)$, MAL A 17406-13. B) Wooded Permafrost Bog (BTX) With Collapse Scars from north of Thompson ( $57^{\circ} 56^{\prime} \mathrm{N}$ and $97^{\circ} 38^{\prime} \mathrm{W}$ ), MAL A 14385-27. C) Wooded Nonpermafrost Bog With Internal Lawns (BTI) from north of The Pas $\left(53^{\circ} 54^{\prime} \mathrm{N}\right.$ and $98^{\circ} 37^{\prime} \mathrm{W}$, MAL A14603-09). D) Wooded Bog Without Internal lawns are found in areas of surface-water stagnation in this large fen occurring in the lee of mineral outcrops and along the margins of the peatland $\left(51^{\circ} 32^{\prime} \mathrm{N}\right.$ and $95^{\circ} 57^{\prime} \mathrm{W}$ ), MAL A 13893-25. E) Domed bogs found in the southeastern part of Manitoba are marked by open, light toned margins, and dark, radiating forested crests $\left(49^{\circ} 24^{\prime} \mathrm{N}\right.$ and $\left.95^{\circ} 24^{\prime} \mathrm{W}\right)$, MAL A37204-55. F) Open Bog With Pools associated with drumlinoid ridge located along a major drainage divide on Washow Bay Point $\left(51^{\circ} 36^{\prime} \mathrm{N}\right.$ and $\left.96^{\circ} 55^{\prime} \mathrm{W}\right), \mathrm{MAL}$ A14634-04. 
folium (Ehrh.) Hedw.. and Polytrichum strictum Brid. This wetland type is typically more heavily forested at the southem limit of its occurrence, with crown closure decreasing as mean annual temperature decreases. The amount of feathermoss cover increases as crown closure increases. Surfaces of collapse scars are typically $100 \mathrm{~cm}$ lower than the surrounding permafrost bog surface and may be present as isolated, circular areals or as interconnected, elongate drainage channels (Figure 6b). Wooded-to-Forested Permafrost Bogs are found from central Manitoba northwards (Figure 5c).

Wooded Nonpermafrost Bogs. With Internal Lawns (BTI). This bog type is characterized by the presence of open, wet, Sphagnum-Carex-dominated internal lawns often containing partially buried stands of dead trees within a uniformly wooded bog island or peninsula (Figure 6c). Common species of Sphagnum occurring in these internal lawns are $S$. angustifolium (Russ.) C. Jens, S. riparium Aongstr., and S. fallax (Klinggr.) Klinggr. On the drier part of these lawns, near the bog margins, hummocks of $S$. fuscum or $S$. magellanicum Bricl. may be found supporting small black spruce trees. These hummocks provide a transition between the bog and the lawn, obscuring the division between them. Surfaces of internal lawns are $40-60 \mathrm{~cm}$ lower than the surrounding nonpermafrost, wooded bog surface and occur in extensive, irregular patterns radiating from the bog island center or in indistinct, nonradiating patterns. Although permafrost is absent, thin, seasonal frost layers can last into late summer. Internal lawns represent areas of permafrust that have historically degraded and may be associated with small bodies of permafrost bog containing relict permafrost (Vitt et al. 1994. Halsey et al. 1995).

Stratigraphic analyses of bogs with internal lawns from Alberta, Saskatchewan, and Manitoba reveal an uppermost layer of about $30.50 \mathrm{~cm}$ of wet, oligotrophic Sphagnum, underlain by a thin layer of sedges, and followed by a layer dominated by Polytrichum strictum or Pleurozium schreberi and abundant wood and/or black spruce needles. Beneath this last layer is a thick layer of a variety of more decomposed macrofossils, all suggesting a habitat of dry wooded bog, indicating that substantial change occurred from a relatively dry, wooded bog habitat to a wet open lawn without transitional phases. Such changes are consistent with thermal subsidence of permafrost peatlands and the ergodic distribution of landforms comprising this wetland form (Vitt et al. 1994). Wooded Nonpermafrost Bogs With Internal Lawns are distributed within a narrow band. spanning central Manitoba from east-to-west (Figure 7a).

Wooded Nonpermafrost Bogs Without Internal Lawns (BTN). Wooded Bogs Without Internal Lawns have a

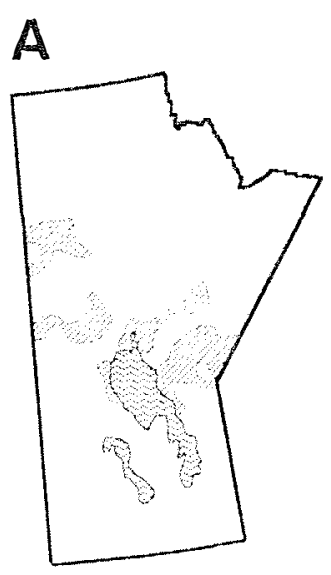

B
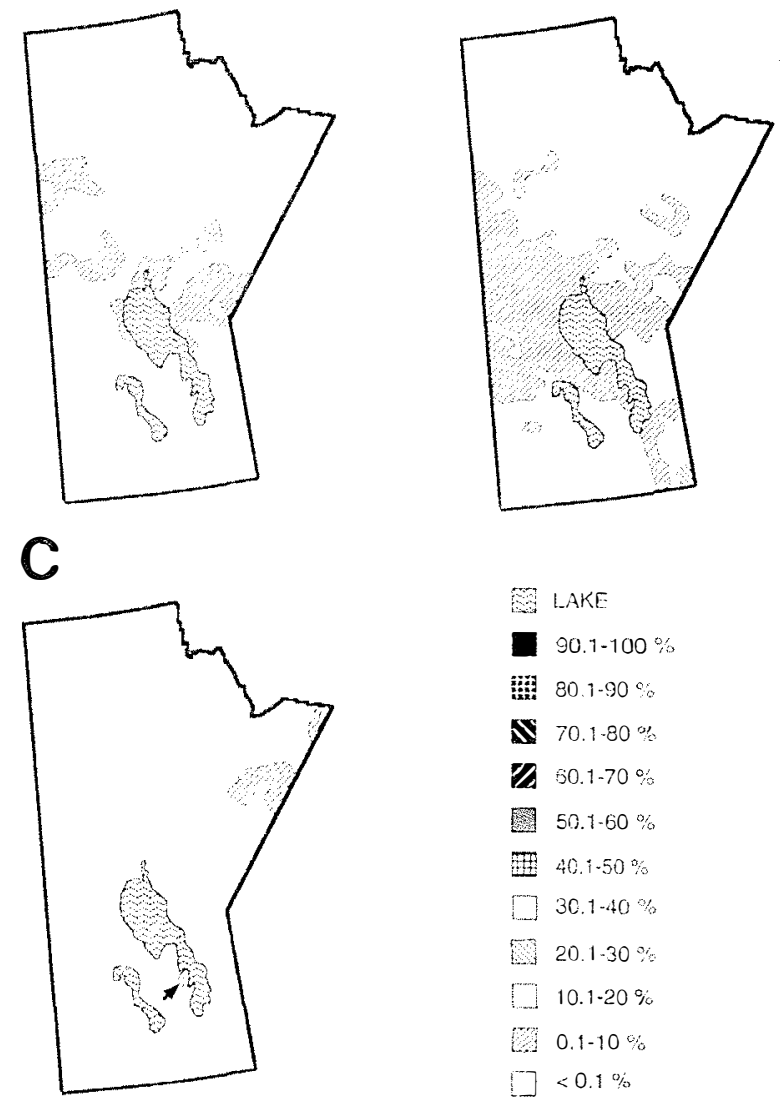

Figure 7. Contoured wetland distribution maps. Legend for $\%$ cover of all maps is at lower right. A) Distribution of Wooded Nonpermafrost Bogs With Internal Lawns, contour interval is $10 \%$ : B) distribution of Wooded Nonpermafrost Bogs Without Internal Lawns, -contour interval is $10 \%$; ) distribution of Open Nonpermafrost Bogs With Pools, -contour interval is $10 \%$.

flat-to-domed, homogenous surface that is uniformly wooded (Figures 6d and 6e). Bogs Without Internal Lawns occur as islands within large complex fens or as peninsulas protruding into large fens. These fens vary from extreme-rich to poor. Bogs can also be found confined to small basins associated with hummocky terrain or in broad, poorly defined depressions as well as along drainage divides. Ground cover is dominated by Sphagnum, and in Manitoba includes S. fuscum, S. rubellum Wils.. S. magellanicum. S. capillifolium, and S. angustifolium. with lichens generally representing $<50 \%$ of the ground cover. Domed bogs (characterized by a forested crest and associated radiating forest pattern (Heinselman $1963 ; 1970$ ), are restricted to the southeasterm corner of Manituba (Figure 7b). These domed bogs represent an important source of horticultural peat for western Canada (Bannatyne 1980).

Open Bogs With Pools (BOP/(X)). Open bogs With Pools are characterized by a domed expanse of Sphag- 
num that sustains an internal ground-water mound. Associated with Open bogs are pools of water that are randomly distributed or crescent-shaped, with the long axis of the pools paralleling the elevational contours of the bog, forming a pattern of hummocks and pools. Pools occur in the central part of the bog and become smaller and less frequent toward the flanks (Figure 6f).

Permafrost has been reported in Open Bogs With Pools within restricted areas, associated with bog pools (Sjörs 1961) and supporting a prominent lichen cover dominated by Flavocetraria nivalis (L.) Kärnefelt \& Thell. Non-permafrost hummocks are composed of Sphagnum fuscum, with S. balticum (Russ.) C. Jens., $S$. rubellum, and $S$. tenellum Hoffm. in hollows (Sjörs 1961). Mud-bottom pools are less than $1 \mathrm{~m}$ in depth and are sporadically ringed with Eriophorum and Carex. Open Bogs With Pools differ from Open Permafrost Bogs as permafrost is restricted to localized areas and is not found under water bodies. Associated with restricted permafrost is the lack of ice wedge formation. Open Bogs With Pools are restricted to the northeastern part of Manitoba, except for one bog located on the western shore of Lake Winnipeg (Figure 7c).

Fens. Vegetative patterns that result from the presence of surface-water flow allow for the distinction of fens from bogs. Fens have been subdivided on the basis of 1) presence of landforms (strings and flarks) oriented perpendicular to surface-water-flow direction(s) in a parallel or reticulate pattern; 2 ) forest cover, with open fens having $\leq 6 \%$ cover and wooded fens having $>$ $6 \%$ cover of Picea mariana and/or Larix laricina (Du Roi) Koch; 3) presence of peat plateaus and internal lawns in wooded fens; and 4) presence of permafrost. Fens are found throughout the province, excluding the southwestern prairies, with high concentrations ( $>$ $40 \%$ cover) north and east of Lake Winnipeg in the vicinity of The Pas and northeast of Lake Manitoba (Figure 8a). The southern limit of fens extends just beyond the southern limit of Larix larcina (Zoltai 1975).

Open Permafrost Fens (FOX). Open Permafrost Fens are characterized by a flat, homogeneous surface dominated by Carex and are at the same elevational level as associated permafrost bogs (Figure 9a). Sphagnum or brown mosses may dominate. Ice wedges, characteristic of fens in the Arctic (NWWG 1988), are not found in Manitoba. Open Permafrost Fens are found exclusively in the extreme northeastern corner of Manitoba (Figure 8b).

Patterned Fens (FOP and FTP). Patterned Fens have a heterogeneous surface characterized by open, wet flarks and drier, shrubby-to-wooded strings and margins (Figure 9b). A Patterned Fen is considered
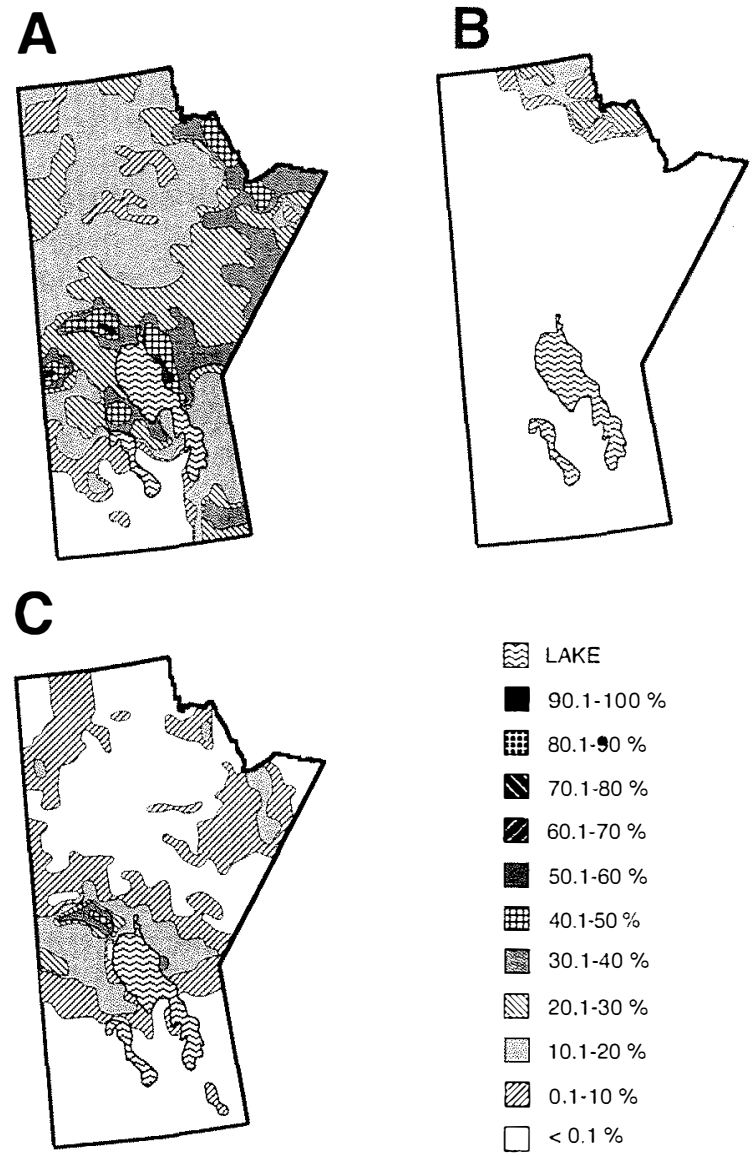

Figure 8. Contoured wetland distribution maps. Legend for $\%$ cover of all maps is at lower right. A) Distribution of all fen landforms in Manitoba, - contour interval is $10 \%$; B) distribution of Open Permafrost Fens, contour interval is $10 \%$; C) distribution of Patterned Fens, - contour interval is $10 \%$.

either open or wooded depending on which component of the patterning (string or flarks) is $>6 \%$. Strings are oriented perpendicular to the direction of water flow, forming sinuous ribs on gently sloping terrain and nets on more level terrain where water flow is multidirectional, resulting in the development of flow interference patterns. String forest cover may be any combination of Larix laricina, Picea mariana, Betula glandulosa Michx., B. pumila L., and Salix spp. Potential ground cover is diverse, ranging from mesotrophic species of Sphagnum in poor fens to Tomenthypnum nitens (Hedw.) Loeske and associated brown mosses in moderate-rich fens to Scorpidium scorpioides (Hedw.) Limpr. and associated brown mosses in extreme-rich fens. Patterned Fens are found in scattered regions throughout the province but are concentrated in central Manitoba and near the mouth of the Churchill River (Figure 8c).

Nonpatterned Open Fens (FON). Nonpatterned 

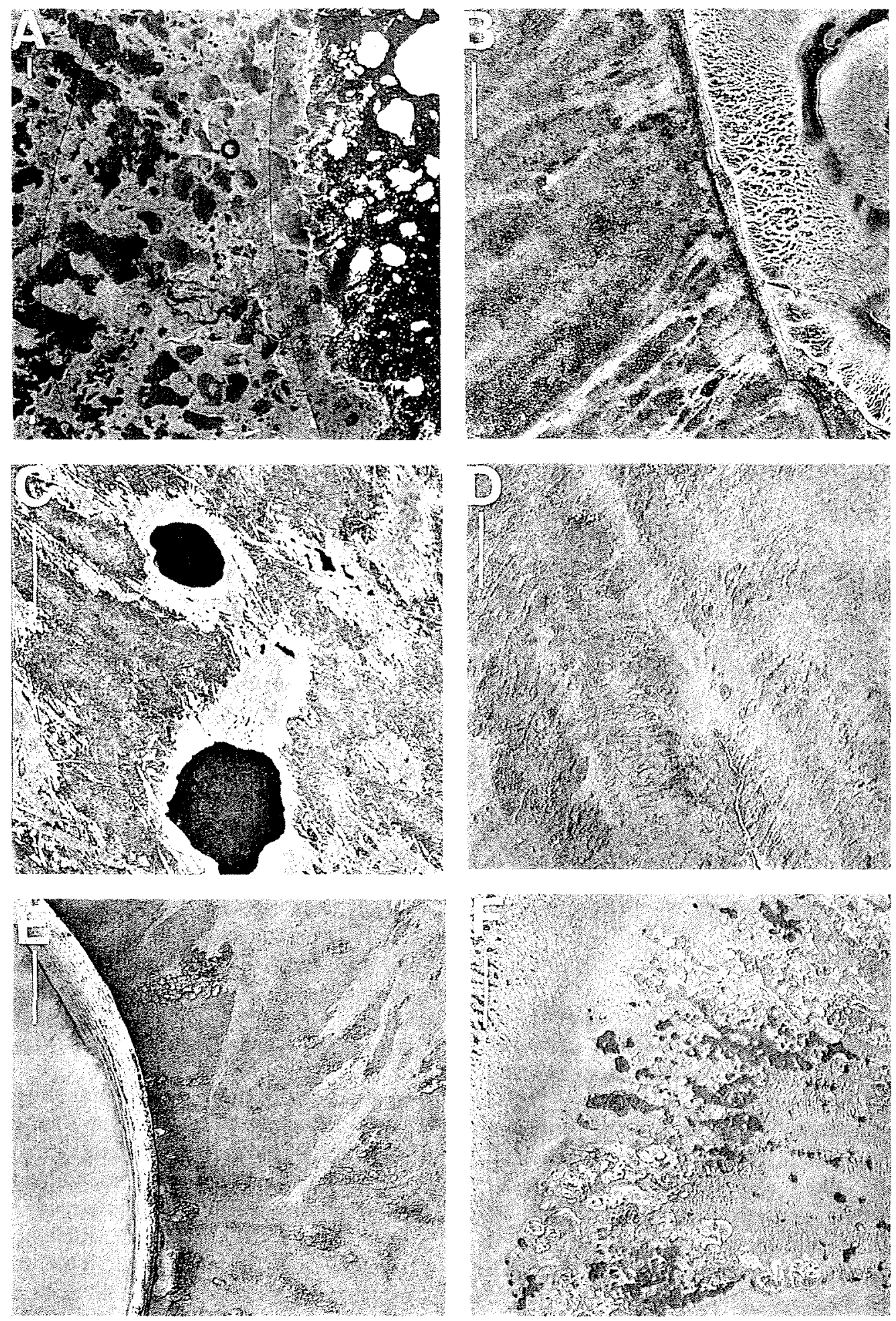

Figure 9. Aerial photographs of fen landforms in Manitoba. Scale bars represent $1 \mathrm{~km}$. A) Open Permafrost Fen (FOX) from the northeastern most part of Manitoba (59 $56^{\prime} \mathrm{N}$ and $94^{\circ} 58^{\prime} \mathrm{W}$ ), MAL A 14676-123. B) Patterned Fens from north of Lake Winnipeg ( $54^{\circ} 07^{\prime} \mathrm{N}$ and $\left.98^{\circ} 45^{\prime} \mathrm{W}\right), \mathrm{MAL}$ A 15950-11. C) Nonpatterned Open Fens within drumlinoid depressions and ice scour features from west of Lake Winnipeg $51^{\circ} 28^{\prime} \mathrm{N}$ and $\left.97^{\circ} 48^{\prime} \mathrm{W}\right)$. A13931-55. D) Nonpatterned Wooded Fen south of The Pas $\left(53^{\circ} 40^{\prime} \mathrm{N}\right.$ and $101^{\circ} 10^{\prime}$ W), MAL A 13929-90. E) Nonpatterned Wooded Fen With Internal Lawns marked by arrows along west shore of Lake Winnipeg near 'The Pas $51^{\circ} 55^{\prime} \mathrm{N}$ and $98^{\circ} 57^{\prime} \mathrm{W}$, MAL A17186-26. F) Nonpatterned Wooded Fen With Internal Lawns and remnants of former forested, permafrost bog northeast of Lake Winnipeg (54 $07^{\prime} \mathrm{N}$ and $\left.98^{\circ} 40^{\prime} \mathrm{W}\right), \mathrm{MAL}$ Al $4650-41$. 

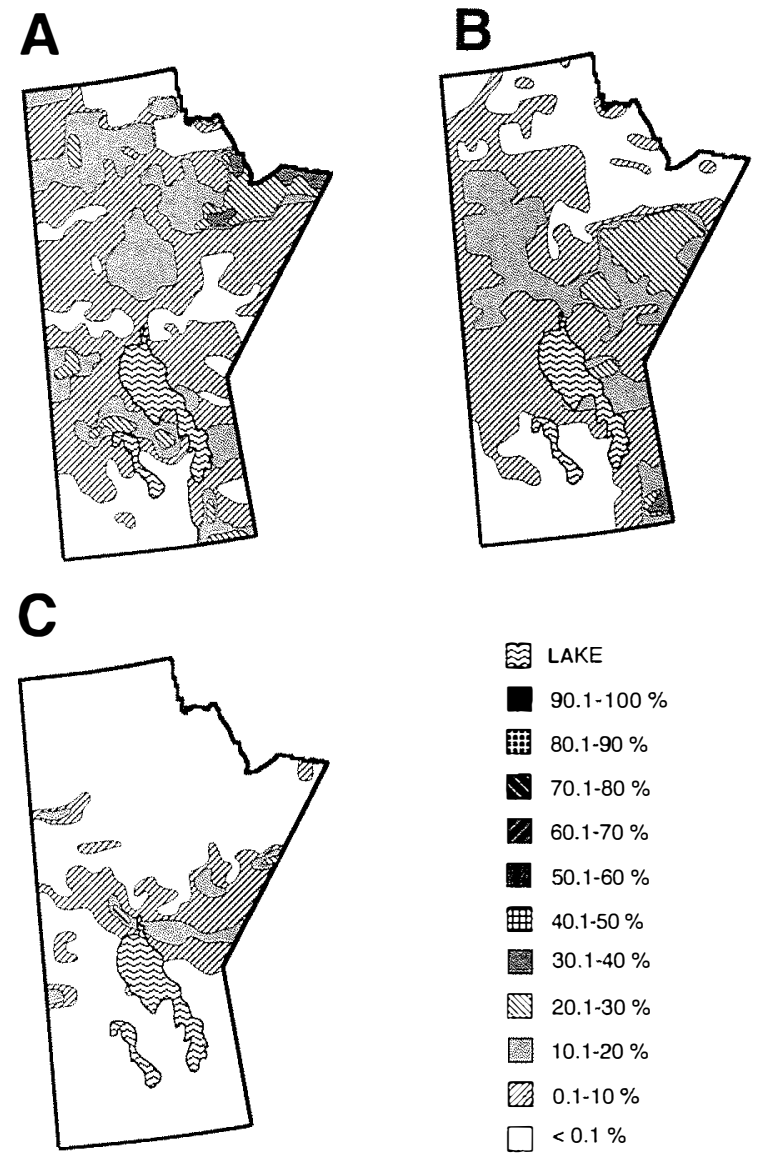

Figure 10. Contoured wetland distribution maps. Legend for \% cover of all maps at lower right. A) Distribution of Nonpatterned Open Fens, contour interval is 10\%; B) distribution of Nonpatterned Wooded Fens, contour interval is $10 \%$; C) distribution of Wooded Fens With Internal Lawns, -contour interval is $10 \%$.

Open Fens are characterized by the presence of a continuous Carex cover, with $\leq 6 \%$ tree cover. Shrubs of Betula and Salix may also be present. Nonpatterned Open Fens occur as collapse scars in association with peat plateaus (Figure $6 \mathrm{~b}$ ) and have a ground cover of Sphagnum (found in wet, poor fens), $S$. riparium, $S$. jensenii $\mathrm{H}$. Lindb., and $S$. angustifolium. Nonpatterned Open Fens can occur as laggs associated with bog islands and have a ground cover characterized by drier oligotrophic species of Sphagnum, such as $S$. russowii Wanrst., S. fallax, or S. angustifolium, with shrubs of Betula and Salix sometimes present. Nonpatterned Open Fens also occur as small isolated basins and as flat, featureless fens that slope gently in the direction of drainage (Figure 9c) and may be poor, moderaterich, or extreme-rich. Nonpatterned Open Fens are found throughout the province excluding the southern prairies (Figure 10a).

Nonpatterned Wooded Fens With No Internal Lawns
(FTN). Nonpatterned, Wooded Fens With No Internal Lawns have $>6 \%$ tree cover of some combination of Picea mariana and/or Larix laricina. An understory of shrubs of Betula and Salix is not uncommon. The ground cover of wooded fens can be domianted by Sphagnum or brown moss. Wooded Fens With No Internal Lawns have a smooth, homogenous surface (Figure 9d). The boundary between wooded fen and mineral upland can be difficult to distinguish and has been determined here on the basis of slope, with wooded fens found only on very gentle slopes. Nonpatterned Wooded Fens With No Internal Lawns can be poor, moderate-rich, or extreme-rich and are found throughout the province, excluding the southwestern prairie area Figure 10b).

Nonpatterned Wooded Fens With Internal Lawns $(F T l)$. In some wooded fens, small, ring-shaped islands with wet depressional centers are present (Figure 9e). The rings are forested almost exclusively with Picea mariana, with individual trees taller than trees in the surrounding wooded fen. Internally, these ring-shaped islands contain wetter and lower areas than the surrounding wooded fen and are internal lawns. These lawns contain standing dead trees and are dominated by graminoid species and wetter species of Sphagnum or brown moss than the surrounding wooded fen. A woody debris layer is present stratigraphically within internal lawns at a depth of $20-40 \mathrm{~cm}$. Plants usually growing under drier conditions, such as Pleurozium schreberi or Tomenthypnum nitens, are present in the woody debris layer. Remnants of these former forested "islands" are occasionally still present, representing degrading permafrost (Vitt et al. 1994) (Figure 9f). Fens With Internal Lawns are distributed in a narrow east-west band across central Manitoba, with areas also found in the Porcupine Hills, The Pas region, and the southern shore of Hudson Bay (Figure 10c).

Marshes (MON). Marshes are distinguished from other wetland forms by lack of tree or shrub cover. Unlike Nonpatterned Open Fens, Marshes require frequent flooding and are found along stream and lake margins and in confined basins associated with Shallow Open Waters (Figure 1 la) and hence, fluctuating water levels. Marshes are found throughout the province but are concentrated in the southern and central regions, particularly around The Pas, Lake Manitoba, and west of Brandon (Figure 12a).

Swamps (SFN, STN, and SON). Swamps are recognized by their location on the landscape next to water bodies that flood frequently or in association with fluctuating water levels such as of ten occur along peatland margins. Unlike Marshes, which do not support a shrub or tree cover due to seasonally wet or regional 

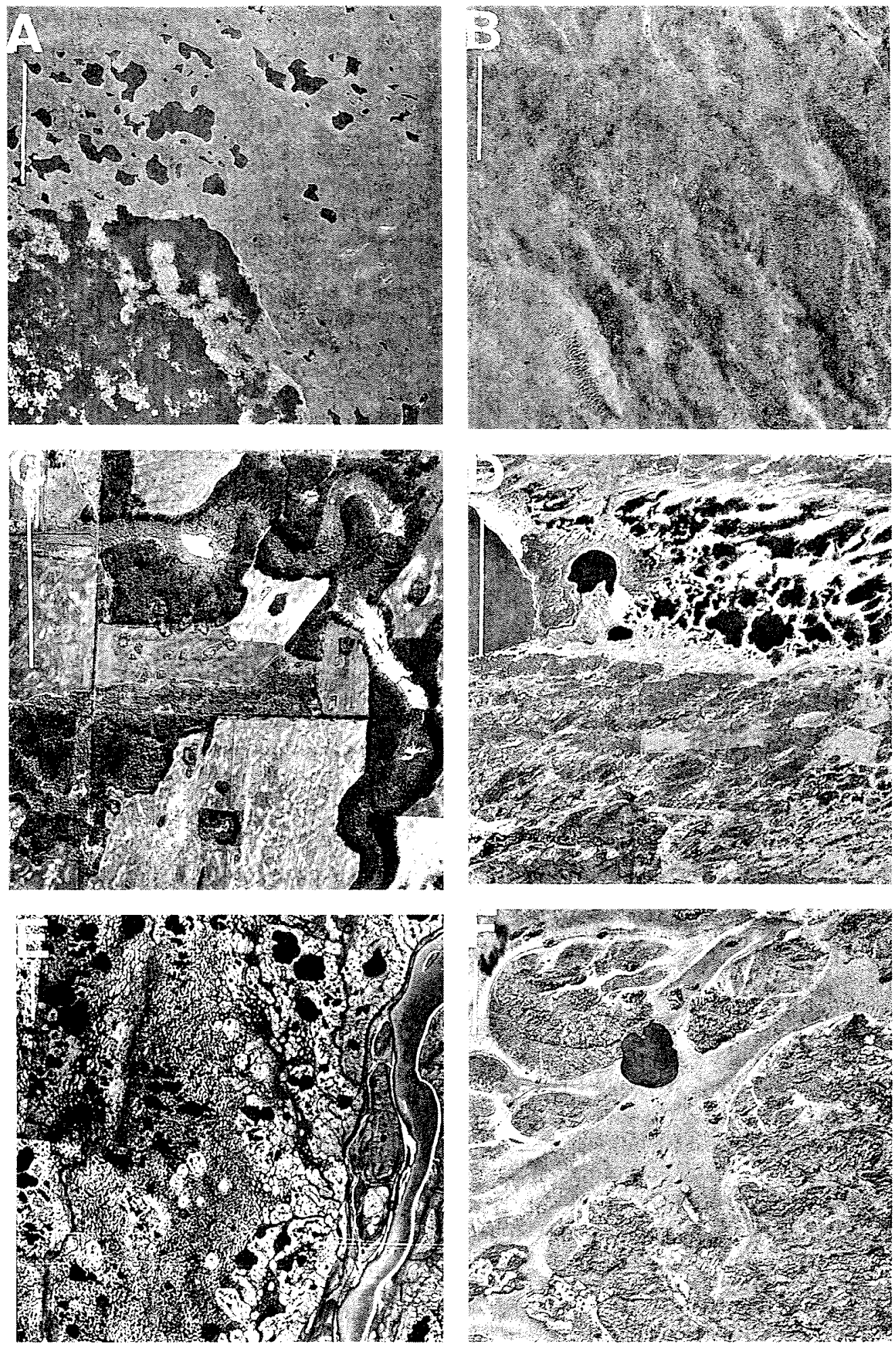

Figure 11. Aerial photographs of non-peat-accumulating wetland landforms in Manitoba. Scale bars represents $1 \mathrm{~km}$. A) Marsh associated with Shallow Open Water, dotted line marks the approximate boundary between marsh and fen, $\left(53^{\circ} 18^{\prime} \mathrm{N}\right.$ and $\left.101^{\circ} 06^{\prime} \mathrm{W}\right), \mathrm{MAL}$ A 13895-69. B) Coniferous Swamp from south of The Pas with $>40 \mathrm{~cm}$ of accumulated peat $\left(53^{\circ} 18^{\prime} \mathrm{N}\right.$ and $101^{\circ} 06^{\prime} \mathrm{W}$ ), MAL A 13895-70. C) Deciduous Swamp along the Whiteshell River (51 $02^{\prime} \mathrm{N}$ and $95^{\circ} 28^{\prime} \mathrm{W}$ ), MAL A13788164. D) Shallow Open Water associated with Marshes from west of Lake Manitoba $\left(51^{\circ} 16^{\prime} \mathrm{N}\right.$ and $\left.99^{\circ} 12^{\prime} \mathrm{W}\right)$, MAL A 1595925. E) Thaw lakes in Open Permafrost Bog in the Hudson Bay Lowland (58 $13^{\prime} \mathrm{N}$ and $\left.64^{\circ} 25^{\prime} \mathrm{W}\right)$, MAL A 17406-10. F) Water bodies associated with peat landforms that are not considered to be shallow open water from east of Lake Winnipeg $\left(53^{\circ} 04^{\prime} \mathrm{N}\right.$ and $\left.96^{\circ} 43^{\prime} \mathrm{W}\right) \mathrm{MAL}$ A 15120-08 
A
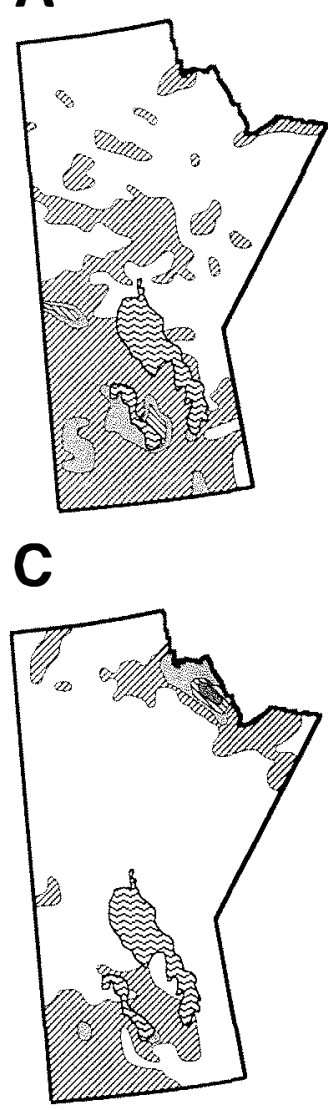
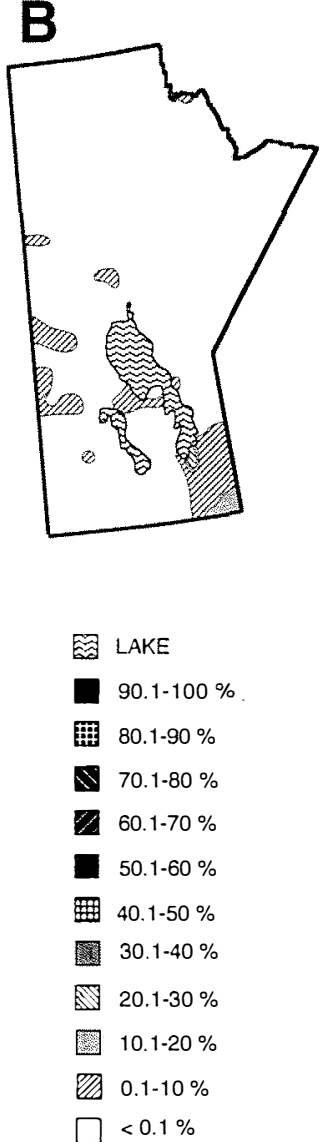

Figure 12. Contoured wetland distribution maps. Legend for \% cover of all maps at lower right. A) Distribution of Marshes, -contour interval is $10 \%$; B) distribution of Swamps, - - contour interval is $10 \%$; C) Distribution of Shallow Open Water, -contour interval is $10 \%$.

climatic conditions, swamps are wooded (coniferous) or covered with shrub (deciduous).

Coniferous Swamps. Coniferous Swamps are forested and have a dense tree cover. They generally have > $70 \%$ cover of some combination of Picea mariana and Larix laricina. They occur in Manitoba in association with floodplains and streams, along the margins of some peatland complexes, and within some broad depressional basins. Tree height is greater in swamps than in fens, as organic accumulation is generally more limited (Figure 1 lb).

Deciduous Swamps. Deciduous Swamps have $>25 \%$ shrub cover dominated by species of Salix that generally grow above shoulder height. Bryophytes are uncommon due to fluctuating water tables. Deciduous Swamps occur along floodplains (Figure $1 \mathrm{lc}$ ), stream terraces, and along peatland margins.

Swamps are found throughout the province but often extend only over small areas, limiting their identification during this mapping study due to constraints
Table 2. Wetland extent for Manitoba.

\begin{tabular}{lrc}
\hline & $\begin{array}{c}\text { Area } \\
\left(\mathrm{km}^{2}\right)\end{array}$ & $\begin{array}{c}\text { Area of } \\
\text { Terrestrial } \\
\text { Wandscape } \\
(\%)\end{array}$ \\
\hline Wooded-to-Forested Bog & & \\
$\quad$ (Nonpermafrost) & 11,351 & 2.1 \\
Wooded-to-Forested Bog & & \\
$\quad$ (Permafrost) & 70,322 & 12.8 \\
Open Bog & & \\
$\quad$ (Nonpermafrost) & 1,026 & 0.2 \\
Open Bog (Permafrost) & 8,030 & 1.5 \\
Patterned Open Fen & 22,710 & 4.1 \\
Nonpatterned Open Fen & & \\
$\quad$ (Nonpermafrost) & 44,674 & 8.2 \\
Nonpatterned Open Fen & & \\
$\quad$ (Permafrost) & 6,790 & 1.2 \\
Wooded-to-Forested Fen & 45,995 & 8.4 \\
Marsh & 13,532 & 2.5 \\
Swamp & 2,055 & 0.4 \\
Shallow Open Water & 6,855 & 1.3 \\
TOTAL & 233,340 & 42.7 \\
\hline
\end{tabular}

imposed on polygon size and percent cover criteria. Mappable units are found on the Boreal Plains and in the southeastern corner of the province (Figure 12b).

Shallow Open Waters (WON). This wetland class is distinguished by its association with other wetland forms, particularly Marshes in the south (Figure 11d) and Open Permafrost Bogs and Fens in the north (Figure 1 le). On aerial photographs, Shallow Open Waters are recognized as small pools of water with smoothto-irregular margins that may be distinct or gradational. Mottling on the water surface is not uncommon and is caused by the presence of emergent vegetation. Water bodies with scalloped margins are often found within peatlands. These water bodies are generally not considered to be Shallow Open Waters, as they are greater than $2 \mathrm{~m}$ in depth and function as aquatic systems. (Figure $1 \mathrm{lf}$ ). Shallow Open Waters are concentrated in southwestern Manitoba, where they are associated with Marshes and in northeastern Manitoba occurring as thaw lakes (Figure 12c).

\section{Wetland Distribution in Manitoba}

Wetlands cover $233,340 \mathrm{~km}^{2}$ or $43 \%$ of Manitoba's terrestrial landscape; fens have the greatest abundance, followed by bogs, marshes, shallow open waters, and swamps (Table 2). Permafrost-dominated peatlands represent $33 \%$ of all wetlands. Peatlands are concentrated in the Hudson Bay Lowland, north and east of Lake Winnipeg, in The Pas region, and the southeastern part of the province (Figure 13a). There are fewer 

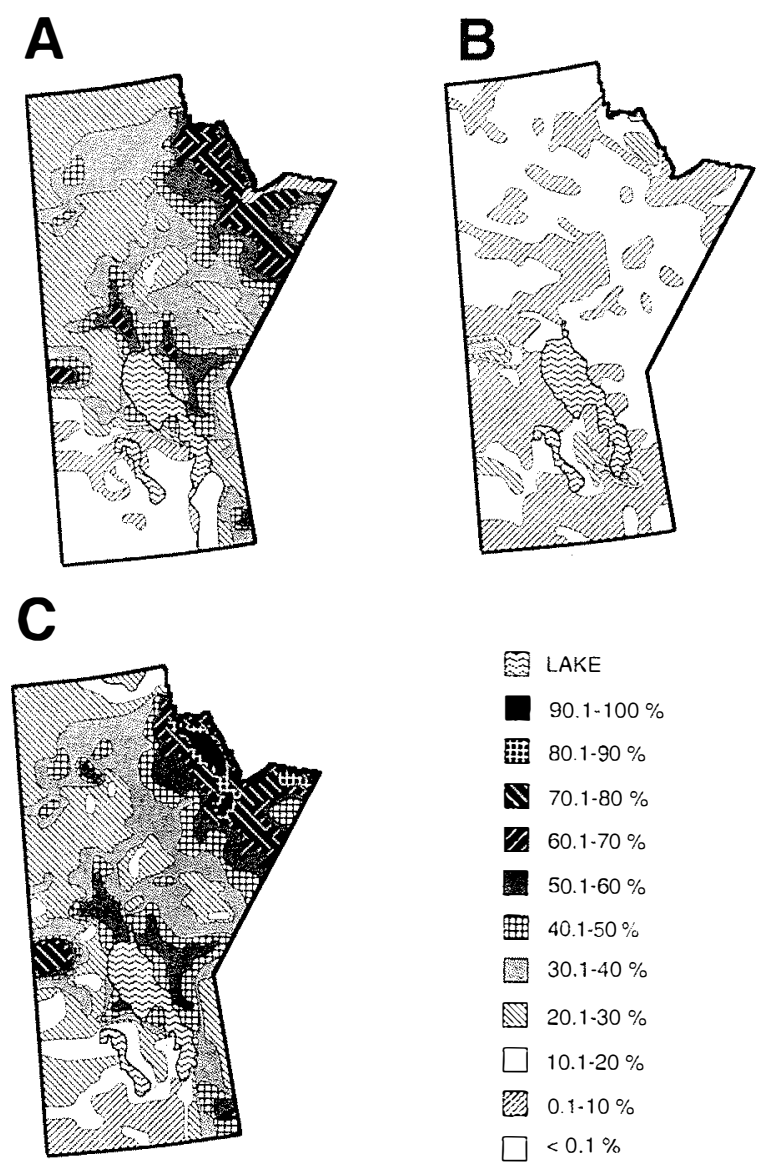

Figure 13. Contoured wetland distribution maps. Legend for \% cover of all maps is at lower right. A) Distribution of peatlands, - - contour interval is $10 \%$; B) distribution of nonpeat-accumulating wetlands, --contour interval is $10 \%$; ) distribution of wetlands, -contour interval is $10 \%$.

non-peat-accumulating wetlands than peatlands (Figure 13b), with regions of relatively high concentrations in the Hudson Bay Lowland and the region of The Pas. The distribution of wetlands (Figure 13c) repre-

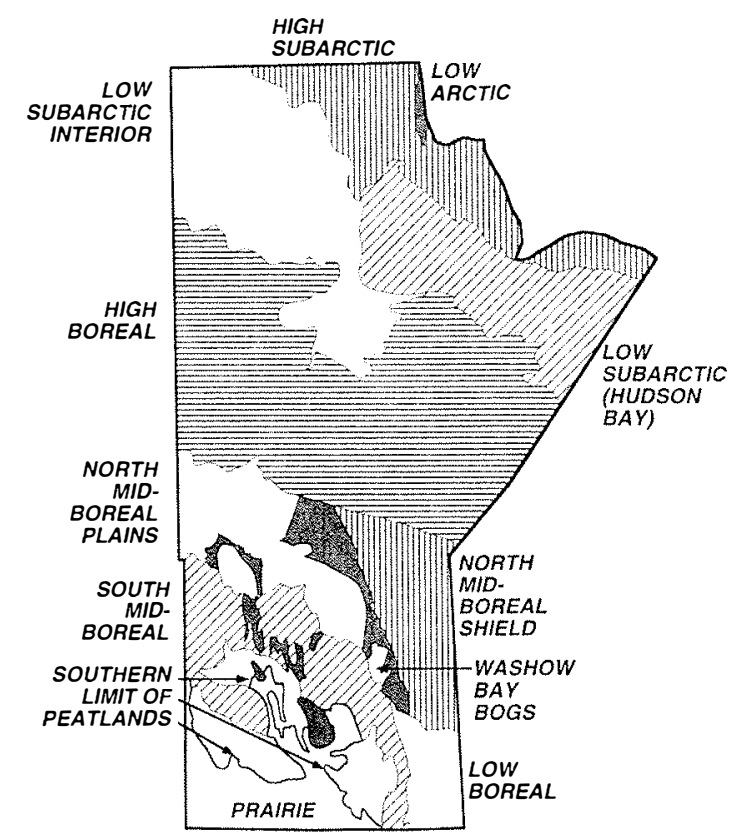

Figure 15. Spatial distribution of wetland regions identified by TWINSPAN.

sents both peatland and non-peat accumulating wetland ecosystems.

\section{Wetland Regions}

The TWINSPAN analysis classified ecodistricts into 11 wetland groups (Figures 14 and 15), each characterized by specific wetland types and abundances. The northeastern most ecodistrict (183) (Figure 1) is not distinguished as a separate group by TWINSPAN; however, it contains no nonpermafrost wetlands and has been classified elsewhere as occurring in the Low/ Southern Arctic (NWWG 1988, Ecological Stratification Working Group 1995). Ice wedges and associated low centered polygons, typical of fens in the Low Arc-

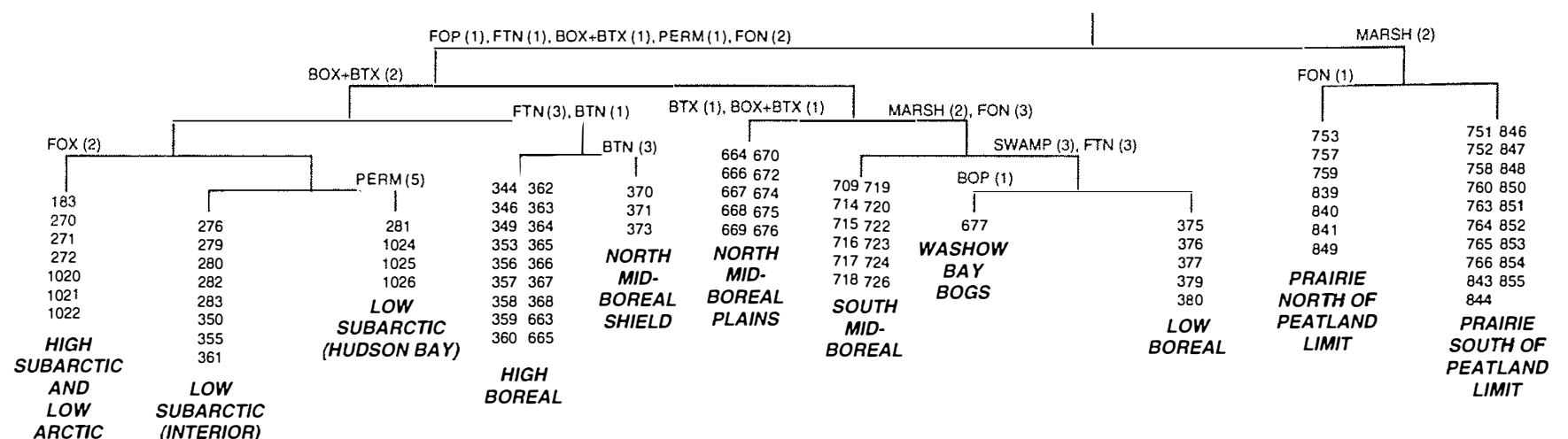

Figure 14. Results of the TWINSPAN classification of wetland abundances by ecodistrict. Cut levels used are 0, 1, 5, 10, and $25 \%$. Indicator wetland types are shown for each cut level. Numbers correspond to ecodistrict numbers in Figure 1. 
tic (NWWG 1988), were not observed on aerial photographs in the northeastern part of Manitoba. The apparent absence of low centered polygons is probably a manifestation of recent marine emergence (ca. < 3,000-4,000 year B. P., Dredge and Nixon [1992]), and associated thin peat cover and not climatic factors. Small, peat-mound bogs, not observable on aerial photographs (1-5 $\mathrm{m}$ in diameter) and typical of arctic peatlands, have been noted in the vicinity (Dredge and Nixon 1992). Thus, this ecodistrict is classified as the Low Arctic Wetland Region.

The High Subarctic Wetland Region is found along the coast of Hudson Bay, extending inland in the north (Figure 15). This wetland region is characterized by Open Permafrost Fens and Open Permafrost Bogs. Bogs typically contain ice wedge polygons and are associated with thaw lakes.

Peat plateaus and associated Open Nonpermafrost Fens dominate the Low Subarctic (Hudson Bay) Wetland Region. High abundances of these two peatland types are the distinguishing wetland characteristic for this wetland region, with combined values exceeding $50 \%$. This area represents the largest tract of organic terrain in North America. Peat plateaus and associated Open Nonpermafrost Fens are also the dominant wetland type of the Low Subarctic (Interior) Wetland Region. Much lower occurrences $(<15 \%)$ of these wetland types distinguish this wetland region from the Low Subarctic (Hudson Bay) Wetland Region (Table 3).

The High Boreal Wetland Region is typified by the presence of Wooded Permafrost and Nonpermafrost Bogs (Table 3). Wooded Nonpermafrost Bogs and Wooded Nonpatterned Fens may contain internal lawns documenting the degradation of permafrost (Vitt et al. 1994). Patterned Fens are common along the southern part of this wetland region.

The Northern Mid-Boreal Shield and Plains Wetland Regions are dominated by fens, with Wooded Nonpermafrost Bogs being present (Table 3). Wooded Permafrost Bogs are found in the northern parts of these wetland region, while internal lawns, representing degraded permafrost, extend into the central part of these wetland regions. The Northern Mid-Boreal Shield can be distinguished from the Northern Mid-Boreal Plains by a greater abundance of Wooded Nonpermafrost Bogs (Table 3).

The Southern Mid-Boreal Wetland Region is also dominated by Wooded and Open Nonpatterned Fens. Permafrost is absent from this wetland region; however, internal lawns do occur in fens within the Porcupine Hills (Ecodistrict 714) (Figure 1), representing the southern-most extent of permafrost during the Little Ice Age (Vitt et al. 1994). Wooded Nonpermafrost Bogs do occur in some areas but are much less com- mon than in the Northern Mid-Boreal Wetland Regions (Table 3).

Wooded Nonpermafrost Bogs are characteristic of the Low Boreal Wetland Region, together with a lack of Wooded Permafrost Bogs (Table 3). Unlike bogs elsewhere in the province, the Low Boreal Wetland Region supports bogs with a forested crest. Open Nonpatterned Fens are also common as are Coniferous Swamps (Table 3).

The Washow Bay Wetland Region is associated most closely with the Low Boreal Wetland Region (Figure 15). Like the Low Boreal Wetland Region, Wooded Nonpermafrost Bogs and Fens are abundant; however, Coniferous Swamps are not. Wooded Nonpermafrost Bogs do not support a forested crest common in the Low Boreal Wetland Region but occur as islands within larger fens or in restricted basins. Also present in this wetland region is a large, Open Bog With Pools, representing 6\% of this ecodistrict (Table 3). The Washow Bay Open Bog With Pools is a unique peatland complex, representing a significant southwestern extention of this peatland type. For this reason it should be preserved.

A cover of $>1 \%$ Marsh and the absence of Patterned and Wooded Nonpatterned Fens characterizes ecodistricts within the Prairie Wetland Region (Figure 15). This wetland region is subdivided into a northern and a southern part defined by the southern limit of peatlands. In the north, Open Nonpatterned Fens occur, while in the south, wetlands are restricted to non-peataccumulating systems.

\section{Relationship of Wetland Type and Distribution to Allogenic Factors}

A hybrid Detrended Canonical Correspondance Analysis (DCCA) was used to examine how environmental factors are associated with wetland distribution in Manitoba. The DCA explains $48.2 \%$ of the variance in the wetland data set on the first four axes, with a $93 \%$ and $50 \%$ correlation generated by the DCCA between the wetland and environmental variables for the first and second axis, respectively (Table 4).

The first axis of the DCA is correlated with both climatic and physiographic parameters, representing variance in the wetland data set that occurs along a north-to-south gradient. In northern Manitoba, permafrost is prevalent in peatlands. The northern area is dominated by Open Permafrost Bogs and Fens of ten associated with thaw lakes. Farther south, Wooded Permafrost Bogs occur. Patterned and Nonpatterned, Open and Wooded Fens With or Without Internal Lawns follow, as do Bogs With Internal Lawns. In the south, Bogs Without Internal Lawns are followed by non-peat-accumulating wetlands dominated by first 
Table 3. Summary of wetland abundances for each wetland region identified by the TWINSPAN classification. Values given are means by ecodistrict with standard deviation in parentheses.

\begin{tabular}{|c|c|c|c|c|c|c|c|c|c|c|c|c|c|c|}
\hline Wetland Region & $\begin{array}{c}\% \\
\text { Cover } \\
\text { BOX }\end{array}$ & $\begin{array}{c}\% \\
\text { Cover } \\
\text { BTX } \\
\end{array}$ & $\begin{array}{c}\% \\
\text { Cover } \\
\text { BTI }\end{array}$ & $\begin{array}{c}\% \\
\text { Cover } \\
\text { BTN } \\
\end{array}$ & $\begin{array}{c}\% \\
\text { Cover } \\
\text { BOP }\end{array}$ & $\begin{array}{c}\% \\
\text { Cover } \\
\text { FOX }\end{array}$ & $\begin{array}{c}\% \\
\text { Cover } \\
\text { FTI }\end{array}$ & $\begin{array}{c}\% \\
\text { Cover } \\
\text { FTN }\end{array}$ & $\begin{array}{c}\% \\
\text { Cover } \\
\text { FOP }\end{array}$ & $\begin{array}{c}\% \\
\text { Cover } \\
\text { FON }\end{array}$ & $\begin{array}{c}\% \\
\text { Cover } \\
\text { MON }\end{array}$ & $\begin{array}{c}\% \\
\text { Cover } \\
\text { SWAMP }\end{array}$ & $\begin{array}{c}\% \\
\text { Cover } \\
\text { WON }\end{array}$ & $\begin{array}{c}\text { Total \% } \\
\text { Cover of } \\
\text { Wetlands }\end{array}$ \\
\hline Low Arctic & $\begin{array}{c}1.35 \\
(0.00)\end{array}$ & $\begin{array}{c}0.57 \\
(0.00)\end{array}$ & $\begin{array}{c}0.00 \\
(0.00)\end{array}$ & $\begin{array}{c}0.00 \\
(0.00)\end{array}$ & $\begin{array}{c}0.00 \\
(0.00)\end{array}$ & $\begin{array}{l}20.08 \\
(0.00)\end{array}$ & $\begin{array}{c}0.00 \\
(0.00)\end{array}$ & $(0.00)$ & $\begin{array}{c}0.00 \\
(0.00)\end{array}$ & $\begin{array}{c}0.00 \\
(0.00)\end{array}$ & $\begin{array}{l}4.11 \\
(0.00)\end{array}$ & $\begin{array}{c}0.00 \\
(0.00)\end{array}$ & $\begin{array}{c}0.92 \\
(0.00)\end{array}$ & 27.03 \\
\hline High Subarctic & $\begin{array}{c}9.94 \\
(11.96)\end{array}$ & $\begin{array}{c}4.48 \\
(3.63)\end{array}$ & $\begin{array}{c}0.00 \\
(0.00)\end{array}$ & $\begin{array}{c}0.00 \\
(0.00)\end{array}$ & $\begin{array}{c}1.42 \\
(3.48)\end{array}$ & $\begin{array}{l}10.79 \\
(4.10)\end{array}$ & $\begin{array}{c}0.23 \\
(0.56)\end{array}$ & $\begin{array}{c}0.78 \\
(0.53)\end{array}$ & $\begin{array}{c}3.14 \\
(2.56)\end{array}$ & $\begin{array}{l}9.16 \\
(9.33)\end{array}$ & $\begin{array}{c}0.53 \\
(0.89)\end{array}$ & $\begin{array}{c}0.00 \\
(0.00)\end{array}$ & $\begin{array}{c}4.16 \\
(7.39)\end{array}$ & 44.63 \\
\hline Low Subarctic Interior & $\begin{array}{c}0.07 \\
(0.18)\end{array}$ & $\begin{array}{l}17.58 \\
(4.60)\end{array}$ & $\begin{array}{c}0.00 \\
(0.00)\end{array}$ & $\begin{array}{c}0.00 \\
(0.00)\end{array}$ & $\begin{array}{c}0.00 \\
(0.00)\end{array}$ & $\begin{array}{c}0.10 \\
(0.27)\end{array}$ & $\begin{array}{c}0.00 \\
(0.00)\end{array}$ & $\begin{array}{c}3.70 \\
(3.44)\end{array}$ & $\begin{array}{c}0.53 \\
(0.65)\end{array}$ & $\begin{array}{c}9.28 \\
(3.30)\end{array}$ & $\begin{array}{c}0.24 \\
(0.29)\end{array}$ & $\begin{array}{c}0.00 \\
(0.00)\end{array}$ & $\begin{array}{c}0.12 \\
(0.27)\end{array}$ & 31.62 \\
\hline Low Subarctic (Hudson Bay) & $\begin{array}{c}0.85 \\
(1.44)\end{array}$ & $\begin{array}{c}39.60 \\
(5.34)\end{array}$ & $\begin{array}{c}0.00 \\
(0.00)\end{array}$ & $\begin{array}{c}0.00 \\
(0.00)\end{array}$ & $\begin{array}{c}0.75 \\
(1.49)\end{array}$ & $\begin{array}{c}0.20 \\
(0.41)\end{array}$ & $\begin{array}{c}0.27 \\
(0.54)\end{array}$ & $\begin{array}{c}1.35 \\
(2.15)\end{array}$ & $\begin{array}{c}2.31 \\
(1.84)\end{array}$ & $\begin{array}{l}14.48 \\
(6.62)\end{array}$ & $\begin{array}{c}0.03 \\
(0.03)\end{array}$ & $\begin{array}{c}0.00 \\
(0.00)\end{array}$ & $\begin{array}{c}0.55 \\
(0.44)\end{array}$ & 60.39 \\
\hline High Boreal & $\begin{array}{c}0.00 \\
(0.00)\end{array}$ & $\begin{array}{l}10.61 \\
(6.52)\end{array}$ & $\begin{array}{c}0.06 \\
(1.21)\end{array}$ & $\begin{array}{c}0.99 \\
(1.42)\end{array}$ & $\begin{array}{c}0.01 \\
(0.03)\end{array}$ & $\begin{array}{c}0.00 \\
(0.00)\end{array}$ & $\begin{array}{c}3.74 \\
(4.74)\end{array}$ & $\begin{array}{c}9.78 \\
(4.99)\end{array}$ & $\begin{array}{c}7.36 \\
(10.58)\end{array}$ & $\begin{array}{c}3.77 \\
(3.19)\end{array}$ & $\begin{array}{c}0.19 \\
(0.23)\end{array}$ & $\begin{array}{c}0.01 \\
(0.03)\end{array}$ & $\begin{array}{c}0.01 \\
(0.03)\end{array}$ & 36.53 \\
\hline North Mid-Boreal Shield & $\begin{array}{c}0.00 \\
(0.00)\end{array}$ & $\begin{array}{c}0.94 \\
(1.06)\end{array}$ & $\begin{array}{c}1.30 \\
(0.61)\end{array}$ & $\begin{array}{c}9.28 \\
(1.83)\end{array}$ & $\begin{array}{c}0.00 \\
(0.00)\end{array}$ & $\begin{array}{c}0.00 \\
(0.00)\end{array}$ & $\begin{array}{c}1.75 \\
(0.53)\end{array}$ & $\begin{array}{c}8.98 \\
(3.16)\end{array}$ & $\begin{array}{c}8.56 \\
(7.03)\end{array}$ & $\begin{array}{c}9.14 \\
(3.17)\end{array}$ & $\begin{array}{c}0.29 \\
(0.21)\end{array}$ & $\begin{array}{c}0.34 \\
(0.26)\end{array}$ & $\begin{array}{c}0.00 \\
(0.00)\end{array}$ & 40.58 \\
\hline North Mid-Boreal Plains & $\begin{array}{c}0.00 \\
(0.00)\end{array}$ & $\begin{array}{c}0.18 \\
(0.38)\end{array}$ & $\begin{array}{c}0.64 \\
(1.25)\end{array}$ & $\begin{array}{l}4.61 \\
(6.45)\end{array}$ & $\begin{array}{c}0.00 \\
(0.00)\end{array}$ & $\begin{array}{c}0.00 \\
(0.00)\end{array}$ & $\begin{array}{c}0.64 \\
(1.45)\end{array}$ & $\begin{array}{c}4.08 \\
(3.01)\end{array}$ & $\begin{array}{l}12.88 \\
(5.31)\end{array}$ & $\begin{array}{c}9.58 \\
(6.90)\end{array}$ & $\begin{array}{c}7.13 \\
(10.29)\end{array}$ & $\begin{array}{c}1.56 \\
(3.02)\end{array}$ & $\begin{array}{c}0.22 \\
(0.38)\end{array}$ & 41.52 \\
\hline South Mid-Boreal & $\begin{array}{c}0.00 \\
(0.00)\end{array}$ & $\begin{array}{c}0.00 \\
(0.00)\end{array}$ & $\begin{array}{c}0.00 \\
(0.00)\end{array}$ & $\begin{array}{c}0.89 \\
(1.35)\end{array}$ & $\begin{array}{c}0.00 \\
(0.00)\end{array}$ & $\begin{array}{c}0.00 \\
(0.00)\end{array}$ & $\begin{array}{c}0.48 \\
(1.72)\end{array}$ & $\begin{array}{c}2.51 \\
(2.14)\end{array}$ & $\begin{array}{c}1.62 \\
(3.62)\end{array}$ & $\begin{array}{c}5.93 \\
(6.01)\end{array}$ & $\begin{array}{c}8.89 \\
(5.28)\end{array}$ & $\begin{array}{c}0.19 \\
(0.28)\end{array}$ & $\begin{array}{c}1.26 \\
(1.67)\end{array}$ & 21.77 \\
\hline Low Boreal & $\begin{array}{c}0.00 \\
(0.00)\end{array}$ & $\begin{array}{c}0.00 \\
(0.00)\end{array}$ & $\begin{array}{c}0.00 \\
(0.00)\end{array}$ & $\begin{array}{c}8.89 \\
(4.90)\end{array}$ & $\begin{array}{c}0.00 \\
(0.00)\end{array}$ & $\begin{array}{c}0.00 \\
(0.00)\end{array}$ & $\begin{array}{c}0.00 \\
(0.00)\end{array}$ & $\begin{array}{l}17.36 \\
(7.26)\end{array}$ & $\begin{array}{c}0.31 \\
(0.29)\end{array}$ & $\begin{array}{c}7.91 \\
(6.47)\end{array}$ & $\begin{array}{c}1.08 \\
(0.73)\end{array}$ & $\begin{array}{c}7.26 \\
(4.56)\end{array}$ & $\begin{array}{l}(0.00) \\
(0.01)\end{array}$ & 42.81 \\
\hline Washow Bay Bogs & $\begin{array}{c}0.00 \\
(0.00)\end{array}$ & $\begin{array}{c}0.00 \\
(0.00)\end{array}$ & $\begin{array}{c}0.00 \\
(0.00)\end{array}$ & $\begin{array}{c}7.87 \\
(0.00)\end{array}$ & $\begin{array}{c}5.93 \\
(0.00)\end{array}$ & $\begin{array}{c}0.00 \\
(0.00)\end{array}$ & $\begin{array}{c}0.00 \\
(0.00)\end{array}$ & $\begin{array}{l}21.01 \\
(0.00)\end{array}$ & $\begin{array}{c}1.08 \\
(0.00)\end{array}$ & $\begin{array}{c}0.54 \\
(0.00)\end{array}$ & $\begin{array}{c}0.32 \\
(0.00)\end{array}$ & $\begin{array}{c}0.00 \\
(0.00)\end{array}$ & $\begin{array}{c}0.00 \\
(0.00)\end{array}$ & 36.75 \\
\hline Prairie North of Peatland Limit & $\begin{array}{c}0.00 \\
(0.00)\end{array}$ & $\begin{array}{c}0.00 \\
(0.00)\end{array}$ & $\begin{array}{c}0.00 \\
(0.00)\end{array}$ & $\begin{array}{c}0.00 \\
(0.00)\end{array}$ & $\begin{array}{c}0.00 \\
(0.00)\end{array}$ & $\begin{array}{c}0.00 \\
(0.00)\end{array}$ & $\begin{array}{c}0.00 \\
(0.00)\end{array}$ & $\begin{array}{c}0.00 \\
(0.00)\end{array}$ & $\begin{array}{c}0.00 \\
(0.00)\end{array}$ & $\begin{array}{c}1.14 \\
(1.26)\end{array}$ & $\begin{array}{c}7.94 \\
(4.29)\end{array}$ & $\begin{array}{c}0.00 \\
(0.00)\end{array}$ & $\begin{array}{c}1.49 \\
(2.31)\end{array}$ & 10.57 \\
\hline Prairie South of Peatland Limit & $\begin{array}{c}0.00 \\
(0.00)\end{array}$ & $\begin{array}{c}0.00 \\
(0.00)\end{array}$ & $\begin{array}{c}0.00 \\
(0.00)\end{array}$ & $\begin{array}{c}0.00 \\
(0.00)\end{array}$ & $\begin{array}{c}0.00 \\
(0.00)\end{array}$ & $\begin{array}{c}0.00 \\
(0.00)\end{array}$ & $\begin{array}{c}0.00 \\
(0.00)\end{array}$ & $\begin{array}{c}0.00 \\
(0.00)\end{array}$ & $\begin{array}{c}0.00 \\
(0.00)\end{array}$ & $\begin{array}{c}0.00 \\
(0.00)\end{array}$ & $\begin{array}{c}7.52 \\
(8.69)\end{array}$ & $\begin{array}{c}0.00 \\
(0.00)\end{array}$ & $\begin{array}{c}3.75 \\
(3.28)\end{array}$ & 11.27 \\
\hline
\end{tabular}


Table 4. Summary of Detrended Correspondence Analysis (DCA) of wetland cover for Manitoba by ecodistrict with allogenic variables.

\begin{tabular}{|c|c|c|c|c|}
\hline Axis & 1 & 2 & 3 & 4 \\
\hline Eigenvalue & 0.72 & 0.21 & 0.13 & 0.06 \\
\hline Length of Gradient & 5.1 & 2.4 & 2.2 & 1.9 \\
\hline Species-environment correlation including ecodistrict 677 & 0.93 & 0.58 & 0.82 & 0.67 \\
\hline Cumulative \% variance of species data explained including ecodistrict 677 & 30.9 & 40.0 & 45.5 & 48.2 \\
\hline Species-environment correlation excluding ecodistrict 677 & 0.94 & 0.69 & 0.75 & 0.57 \\
\hline Cumulative \% variance of species data explained excluding ecodistrict 677 & 31.4 & 39.9 & 45.4 & 47.8 \\
\hline
\end{tabular}

Swamps, and then Marshes and Shallow Open Waters (Figure 16).

Mean annual temperature is the most important and significant environmental variable correlated to the first axis (Figure 17, Table 5). Mean annual temperatures have been correlated to permafrost distribution (Vitt et al. 1994, Halsey et al. 1995), with permafrost distribution increasing in bogs as mean annual temperatures decrease.

Also important along the first axis are climatic variables that control the hydrology of wetlands, specifically thermal seasonal aridity index (TSAI), yearly precipitation, and moisture deficit (Figure 17, Table 5). While TSAI, yearly precipitation, and moisture deficit

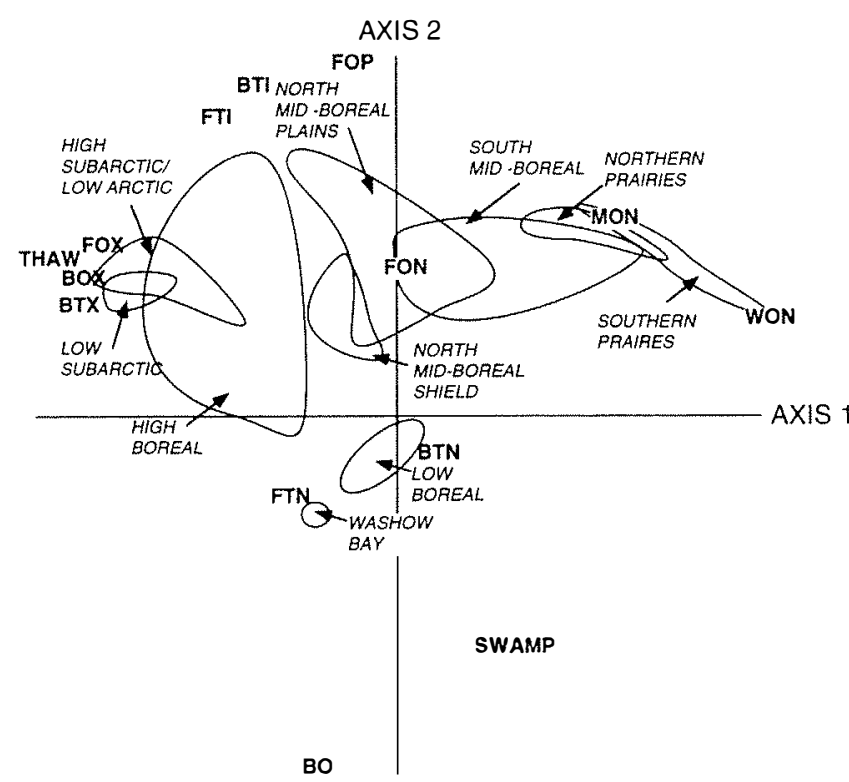

Figure 16. DCA ordination of TWINSPAN wetland regions and wetland landform types. $\mathrm{BOX}=$ Open Permafrost Bog; $\mathrm{FOX}=$ Open Permafrost Fen; THAW = thaw lakes (Shallow Open Water); BTI = Nonpermaf rost Wooded Bogs With Internal Lawns; FTI = Nonpatterned Wooded Fens With Internal Lawns; BTN = Nonpermafrost Wooded Bogs; FTN = Nonpatterned Wooded Fens; BOP = Open Bogs With Pools; FOP = Patterned Fens; FON = Nonpatterned Open Fens; MON = Marsh; and WON = Shallow Open Water. are all correlated to some degree, they are each significant and canonically important to the first axis, suggesting that each allogenic variable is explaining different components of the variation. Of these variables, TSAI has the highest significance and previously has been linked to the southern limit of peatlands in western continental Canada (Zoltai and Vitt 1990).

Bedrock is an important canonical and statistically significant allogenic variable to the first axis. Bedrock geology in Manitoba can be subdivided into three general types: 1) acidic granite and granitoid gneisses of Precambrian age; 2) calcareous shales, dolomites, and limestones of Paleozoic Age; and 3) calcareous shales and sands of Mesozoic and Cenozoic Age. Ecodistricts dominated by acidic Precambrian rocks have a greater abundance of bogs than with similar climatic condi-

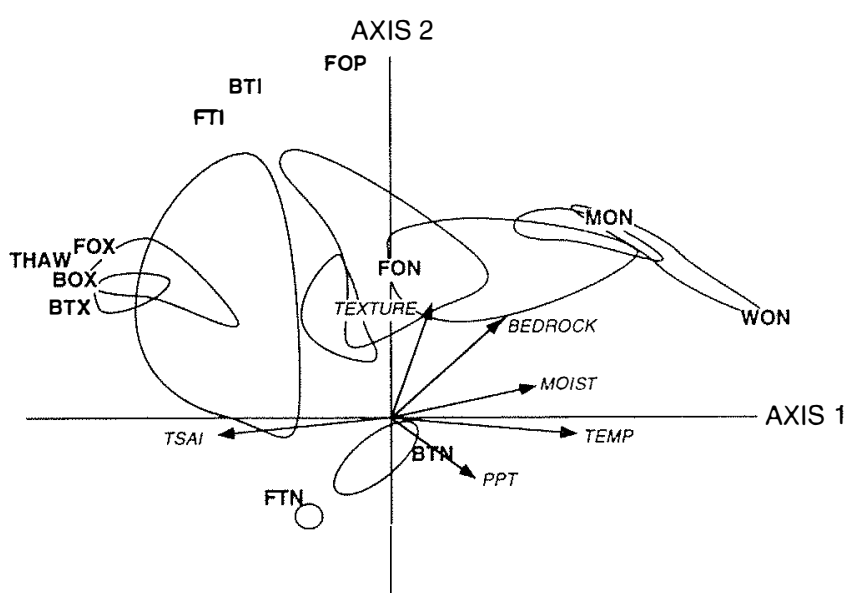

SWAMP

BO

Figure 17. DCA ordination of TWINSPAN wetland regions and landform types (see Figure 16 for landform abbreviations) overlain with significant and important allogenic variables from the hybrid DCCA. The Washow Bay Wetland Region is excluded from the DCCA. Temp = mean annual temperature; $\mathrm{PPT}=$ yearly precipitation; bedrock = bedrock geology; moist $=$ moisture deficit calculation; and TSAI = thermal seasonal aridity index. 
Table 5. Statistics for variables used in the DCA of wetland data to climatic and physiographic controls A) with all ecodistricts included and B) excluding the Washow Bay Wetland Region. Asterisks indicate significance at $p=0.005$. Absolute $t$-values $>2.1$ are used to indicate important canonical coefficients (ter Braak 1988). Bold values are indicated for variables with significant correlation and canonical coefficients.

\begin{tabular}{|c|c|c|c|c|c|c|}
\hline \multirow[b]{2}{*}{ Variable } & \multicolumn{2}{|c|}{$\begin{array}{c}\text { Interset } \\
\text { Correlation }\end{array}$} & \multicolumn{2}{|c|}{$\begin{array}{l}\text { Canonical } \\
\text { Coefficient }\end{array}$} & \multicolumn{2}{|c|}{$t$-Value } \\
\hline & Axis 1 & Axis 2 & Axis 1 & Axis 2 & Axis 1 & Axis 2 \\
\hline \multicolumn{7}{|l|}{ A) } \\
\hline Mean annual temp. & * 0.87 & -0.06 & * 0.84 & $*-0.64$ & 3.9 & -3.2 \\
\hline TSAI & $*-0.85$ & -0.04 & $*-0.54$ & $*-0.54$ & -2.3 & -2.5 \\
\hline Yearly precipitation & * 0.39 & -0.18 & $*-0.15$ & -0.00 & -2.2 & -0.0 \\
\hline Moisture deficit & * 0.70 & 0.09 & $*-0.42$ & 0.05 & -3.8 & 0.5 \\
\hline Topography & -0.10 & -0.07 & 0.06 & -0.05 & 0.9 & -0.8 \\
\hline Texture & 0.19 & $* 0.31$ & 0.03 & $* 0.25$ & 0.3 & 2.3 \\
\hline Bedrock geology & * 0.54 & 0.27 & 0.28 & 0.14 & 4.6 & 2.6 \\
\hline Frost free days & 0.06 & -0.03 & -0.01 & -0.01 & -0.1 & -0.1 \\
\hline Growing index & 0.19 & 0.03 & 0.02 & 0.02 & 0.2 & 0.1 \\
\hline \multicolumn{7}{|l|}{ B) } \\
\hline Mean annual temp. & * 0.88 & -0.07 & $* 0.85$ & $*-0.55$ & 3.9 & -3.3 \\
\hline TSAI & $*-0.85$ & -0.02 & $*-0.53$ & $*-0.49$ & -2.2 & -2.7 \\
\hline Yearly precipitation & * 0.39 & $*-0.30$ & $*-0.15$ & -0.06 & -2.2 & -1.2 \\
\hline Moisture deficit & * 0.70 & 0.05 & $*-0.41$ & 0.04 & -3.7 & 0.5 \\
\hline Topography & -0.10 & -0.18 & 0.07 & -0.05 & 1.1 & -0.9 \\
\hline Texture & 0.19 & * 0.34 & 0.06 & $* 0.32$ & 0.5 & 3.4 \\
\hline Bedrock & * 0.52 & 0.36 & 0.28 & 0.14 & 4.5 & 3.0 \\
\hline Frost free days & 0.06 & -0.02 & -0.02 & -0.05 & -0.1 & -0.6 \\
\hline Growing index & 0.18 & 0.15 & 0.02 & 0.07 & 0.2 & 0.7 \\
\hline
\end{tabular}

tions underlain by calcareous bedrock. Clearly, the presence of calcareous bedrock serves as a buffer to acidification and oligotrophication and limits or delays the development of bogs.

On the second axis, Patterned Fens occur at one end and Nonpermafrost Bogs at the other, while corresponding non-peat-accumulating wetlands have Marshes and Shallow Open Waters grading to Swamps. Patterned Fens have large amounts of surface-water flow relative to bogs, while Marshes and Shallow Open Waters have more annual surface-water flow than do Swamps (NWWG 1988).

Texture of the underlying mineral soil is the most important allogenic variable correlated to the second axis (Table 5). When the texture of the underlying mineral soil is fine-grained and hydraulic conductivity is low, peatlands with small amounts of surface-water flow (bogs) are more abundant, while in areas where the underlying mineral soil has a higher hydraulic conductivity, peatlands with large amounts of surface-water flow (Patterned Fens) occur. Similar edaphic controls on more local peatland distribution have been noted in Minnesota (Glaser 1992). Bedrock geology also plays a canonically important and statistically significant role in explaining variation on the second axis, just as it did on the first, following the same pattern as with the first axis.

Of the peat accumulating wetlands, Patterned Fens are found at one extreme of the second axis with Nonpermafrost Fens and Bogs at the other; in between are peatland types containing degraded permafrost features. At the southern permafrost limit, permafrost is a relatively recent phenomena (Vitt et al. 1994) and only transitory (Halsey et al. 1995); however, seasonal frost will persist for longer periods in cooler areas, allowing for an alternate source of surface water longer into the growing season. As permafrost becomes more and more common in peatlands, this source of surface water decreases, corresponding to a decrease in the thickness of the active layer.

The association of Patterned Fens to the southern limit of discontinuous permafrost has long been suggested in the literature and generated the original hypothesis on string and flark formation as being a manif estation of cryoterbation (Tanttu 1914). Since that time, other workers have hypothesized that permafrost processes in fens are manifested by the development of patterning (Hamelin 1957, Schenk 1966). These hypotheses have been largely discredited, as Patterned Fens are known to exist well south of the influence of 
permafrost (Foster et al. 1983). The association of Patterned Fens with degraded permafrost features on the DCA suggests that Patterned Fens occur preferentially in Manitoba where seasonal frost persists well into the growing season. This additional source of surface water may be enough to permit the development of strings and flarks in areas where they would not develop to the south without this additional influx. Temperature and TSAI, although not statistically significant, are canonically important to the second axis.

When all ecodistricts are placed into the DCA, the allogenic variables explain $58 \%$ of the variation on the second axis (Table 4). When the Washow Bay Wetland Region is removed, the ability for the allogenic variables to explain the second axis improves to $69 \%$ and yearly precipitation becomes statistically significant (Table 5).

The location of the Washow Bay Wetland Region on the DCA is largely controlled by its great abundance of Open Bogs With Pools. Open Bogs With Pools occur in other regions where the influx of moisture greatly exceeds the efflux (Auer 1928, Damman 1979, Ivanov 1981, Glaser and Janssens 1986, Foster et al. 1988). A bog landform gradient of Wooded Bog Islands, Wooded Bogs With Forested Crests, and Open Bogs With Pools has been established within eastern North America and has been correlated to increasing oceanity (Damman 1979, Glaser and Janssens 1986). The proximity of the Washow Bay Wetland Region to the South Mid-Boreal Wetland Region and lack of wooded bogs with forested crests in the area suggests that the Open Bog With Pools occurring within this wetland region has not developed exclusively as a result of climatic controls, although the local climate is somewhat modified by Lake Winnipeg.

Allogenic factors controlling peatland development are not restricted to climatic variables. The topography, texture, and configuration of the underlying mineral soil units also have been recognized as important factors in controlling wetland distribution, playing an important role in wetland hydrology (Glaser 1992). The Washow Bay Open Bog With Pools is located along a regional drainage divide and surrounds a drumlinoid ridge composed of a till that contains a great amount of gravel and sand (Nielsen et al. 1981). This ridge may have an associated ground-water mound. Similar hydrogeological conditions have been noted in other peatland complexes in association with linear ridges ( i.e., Siegel 1992). The juxtaposition of regional and local ground-water-flow systems complement each other, allowing for a greater influx of water than would normally occur and allowing for the development of pools and restriction of tree growth.

Although the ecodistrict comprising the Washow Bay Wetland Region (677) (Figure 1) has a relatively low amount of yearly precipitation, the DCA ordinated it to the part of the second axis corresponding to high precipitation on the DCCA. Thus, when it is not placed in the ordination, precipitation becomes statistically significant on the second axis, with wetlands of the North Mid-Boreal Plains receiving relatively small amounts of precipitation, while wetlands of the Low Boreal receive relatively large amounts of precipitation. Bog abundance is greater in the Low Boreal Wetland Region, as precipitation is greater allowing for the more rapid development of ground-water mounds and hence bogs.

\section{CONCLUSIONS}

Wetlands in Manitoba represent a large amount of the terrestrial landscape; these wetlands are dominated by minerotrophic fens. Twelve wetland regions are identified for the Province, each characterized by specific wetland types and abundances developed largely through multivariate analyses. Permafrost Fens associated with peat mound bogs are typical of the Low Arctic, while Permafrost Bogs and Fens dominate the Subarctic. Open Permafrost Bogs dominate the High Subarctic, and Wooded Permafrost Bogs the Low Subarctic. A great abundance of peatlands ( $>60 \%$ ) typify the Low Subarctic (Hudson Bay) Wetland Region, while a lesser abundance (30\%) is characteristic of the Low Subarctic (Interior) Wetland Region. Wetland regions of the High to Mid-Boreal Forest are typified by a diverse assemblage of all wetland types, excluding Open Permafrost Fens. Nonpermafrost Wooded Bogs and Fens occur more commonly in the Low Boreal than in the Southern Mid-Boreal Wetland Region, characterizing this wetland region along with the relatively great abundance of Coniferous Swamps. The presence of Open Bogs With Pools and lack of permafrost peatlands characterize the Washow Bay Wetland Region. Within the prairies, two wetland regions are noted, one north of the southern limit of peatlands supporting Open Nonpatterned Fens and one south of the southern limit of peatlands containing only nonpeat-forming wetlands.

Climatic factors of mean annual temperature, thermal seasonal aridity, yearly precipitation, and moisture deficit are all important allogenic variables explaining wetland distribution in Manitoba. Second to climatic factors in explaining wetland distribution are the physiographic parameters of bedrock geology and texture of the underlying mineral soil.

The distribution of wetlands across Manitoba is a manifestation of its climate and geology, both of which control the hydrology of these ecosystems. Wetlands, are sensitive ecosystems, responding to small changes in hydrology (Gignac and Vitt 1990, Gignac et al. 
1991, Gorham and Janssens 1992, Nicholson et al. 1996). Regional changes in climate (Halsey et al. 1995. Nicholson et al. 1996), or anthropogenic alteration of the hydrological balance of watersheds supporting wetlands (Gosselink and Maltby 1990, Gorham 1991a, 1991b) will all impact the distribution of wetlands. Responsible management of these delicate ecosystems is required to maintain the health and integrity of the overall landscape.

\section{ACKNOWLEDGMENTS}

This research was supported by a grant from the Canadian Forest Service under the Canada-Manitoba Partnership Agreement in Forestry and from NSERC Strategic and Research Grants to Dale Vitt. We are grateful to Drs. J.-S. Vincent, L. Dredge, and R. Klassen of the Geological Survey of Canada for providing aerial photo cover for the province north of $56^{\circ}$ and to Hilarie Stevens and Gay Fortier for their assistance in the field. Dr. H. Velduis provided us access to the climatic ecodistrict data compiled by Agriculture Canada, and Dr. W. Pettapiece provided us with the ecodistrict framework for the province, for which we are grateful. Reviews by G. Matile, N. Roulet, and an anonymous reviewer greatly improved this manuscript.

\section{LITERATURE CITED}

Auer, V. 1928. Present peat bogs in southeastern Canada. Communicationes Instituto Forestalium Finlandica 13:1-48.

Almquist-Jacobson, H. and D. R. Foster. 1995. Toward an integrated model for raised bog development: theory and field evidence. Ecology 76:2503-2516.

Bannatyne, B. B. 1980. Sphagnum bogs in southern Manitoba and their identification by remote sensing. Manitoba Energy and Mines Economic Geology Report ER79-7.

Crum, H. 1988. A Focus on Peatlands and Peat Mosses. The University of Michigan Press, Ann Arbor, MI. USA.

Damman. A. W. H. 1979. Geographic patterns in peatland development in eastern North America. p. 42-52. In Proceedings of the International Symposium on Classification of Peat and Peatlands, Hyytiäiä, Finland.

Dridge, L. A. and F. M. Nixon. 1992. Glacial and environmental geology of northeastern Manitoba. Geological Survey of Canada Memoir 432

Dredge, L. A.. F. M. Nixon, and R. J. Richardson. 1986. Quaternary geology and geomorphology of northwestern Manitoba. Geological Survey of Canada Memoir 418.

Ecological Stratification Working Group. 1995. Terrestrial ecozones, ecoregions, and ecodistricts of Canada: Provinces of Alberta, Saskatchewan, and Manitoba. A national ecological framework for Canada. Agriculture and Agri-Foods Canada, Research Branch Centre for Land and Biological Resources Research and Environment Canada. State of the Environment Directorate, Ecozone Analysis Branch, Ottawa/Hull. Ontario, Canada.

Environment Canada. 1982. Canadian Climate Normals 19511980, Volumes 2 and 3. Atmospheric Environment Service, Ottawa, Ontario, Canada.

Foster, D. R., G. A. King, P. H. Glaser, and H. E. Wright, Jr. 1983. Origin of string patterns in boreal peatlands. Nature 306:256-258.

Foster, D. R., H. E. Wright, Jr., M. Thelaus, and G. A. King. 1988. Bog development and landform dynamics in central Sweden and south-eastern Labrador, Canada. Journal of Ecology 76:11641185.

Gauch. Jr., H. G. 1982. Multivariate Analysis in Community Ecology. Cambridge University Press, Cambridge. UK.

Gignac, L. D. and D. H. Vitt. 1990. Habitat limitation of Sphagnum along climatic, chemical, and physical gradients in mires of western Canada. The Bryologist 93:7-22.

Gignac, L. D. and D. H. Vitt. 1994. Responses of northern peatlands to climate change: effects on bryophytes. Journal of the Hattori Botanical Laboratory 75: 119-132.

Gignac, L. D., D. H. Vitt, S. C. Zoltai, and S. E. Bayley. 1991. Bryophyte response surfaces along climatic gradients in mires of western Canada. Nova Hedwigia 53:27--71.

Glaser, P. H. and J. A. Janssens. 1986. Raised bogs in eastern North America: transitions in landforms and gross stratigraphy. Canadian Journal of Botany 64:395-415.

Glaser, P. H. 1992. Peat landforms. p. 3-14. In H. E. Wright, B. A. Coffin, and N. E. Aaseng (eds.) The Patterned Peatlands of Minnesota, The University of Minnesota Press, Minneapolis, MN, USA.

Gore, A. J. P. 1983. Ecosystems of the World 4B. Mire: Swamp, Bog, Fen, and Moor. Regional Studies, Elsevier Scientific Publ. Co., Amsterdam, The Netherlands.

Gorham, E. 1991a. Northern peatlands: role in the carbon cycle and probable responses to climatic warming. Ecological Applications 1:182-195.

Gorham, E. 1991b. Human influences on the health of northern peatlands. Transactions of the Royal Society of Canada 6:199 208.

Gorham, E. and J. Janssens. 1992. The paleorecord of geochemistry and hydrology in northern peatlands and its relation to global change. Suo 43:117-126.

Gooselink, J. G. and E. Maltby. 1990. Wetland losses and gains. p. 296-322. In M. Williams (ed.) Wetlands: A Threatened Landscape, Basil Blackwell Ltd.. Oxford, England.

Halsey, L. A., D. H. Vitt, and S. C. Zoltai. 1995. Disequilibrium response of permafrost in boreal continental western Canada to climatic change. Climatic Change 30:57-73.

Halsey, L. A.. D. H. Vitt, S. C. Zoltai, and H. Stevens. 1997. The wetlands of Manitoba: A 1:1,000,000 summary map. Geological Services, Manitoba Energy and Mines, Winnipeg, Manitoba, Canada.

Hamelin, L. E. 1957. Les tourbiers reticulées du Québec-Labrador subarctique: interprétation morphoclimatique. Cahiers Géographie de Quebec 17:87-106.

Heinselman, M. L. 1963. Forest sites, bog processes, ancl peatland types in the Glacial Lake Agassiz Region, Minnesota. Ecological Monographs 33:327-374.

Heinselman, M. L. 1970. Landscape evolution, peatland types, and the environment in the Lake Agassiz peatlands natural area, Minnesota. Ecological Monographs 40:235-261.

Hill, M. O. 1979. TWINSPAN-A Fortran program for arranging multivariate data in an ordered two-way table by classification of the individuals and attributes. Cornell University. Ithaca, NY, USA.

Hogg, E. H. 1994. Climate and the southern limit of the western Canadian boreal forest. Canadian Journal of Forest Research 24: $1835-1845$.

Ivanov, K. E. 1981. Water movements of mirelands. Translated from the Russian Vodoobmen v bototnykh landasgaftakhh (1975) by $\mathrm{A}$. Thompson and H. A. P. Ingram, Academic Press, London, England.

Klassen, R. W. 1986. Surficial geology of north-central Manitoba. Geological Survey of Canada Memoir 419.

Kuhry, P., B. J. Nicholson, L. D. Gignac, D. H. Vitt, and S. E. Bayley. 1993. Development of Sphagnum-dominated peatlands in boreal continental Canada. Canadian Journal of Botany 71:1022

Manitoba Mineral Division. 1994. Geologic highway map of Manitoba. Manitoba Energy and Mines. Winnipeg. Manitoba, Canada.

National Wetlands Working Group. 1988. Wetlands of Canada. Ecological Land Classification Series No. 24. Sustainable Develop- 
ment Branch, Environment Canada, Ottawa. Ontario, and Polyscience Publications Inc.. Montreal, Quebec, Canada.

Nicholson, B. J., L. D. Gignac, S. E. Bayley, and D. H. Vitt. 1996. Vegetation response to global warming: interaction between boreal forest. wetlands and regional hydrology. Final Report MacKenzie Basin Impact Study (in press).

Nielsen, E., S. M. Ringrose, G. L. D. Matile, H. D. Groom, M. A. Mihychuk, and G. G. Conley. 1981. Surficial Geological Map of Manitoba. Manitoba Mineral Resources Division Map 81-1.

RockWare. 1991. Macgridzo: The contour mapping program for the Macintosh Version 3.3, RockWare, Wheat Ridge, CO, USA.

Schenk, E. 1966. Origin of string bogs. p. 155-159. In Proceedings of the International Permafrost Conference. National Academy of Science, Washington, DC, USA.

Seigel, D. I. 1992. Groundwater hydrology. p. 163-172. In H. E. Wright, B. A. Coffin, and N. E. Aaseng (eds.) The Patterned Peatlands of Minnesota, The University of Minnesota Press, Minneapolis, MN, USA.

Sjörs, H. 1961. Forest and peatland at Hawley Lake, northern Ontario. National Museum of Canada Bulletin 1971:1-31.

Sjörs, H. 1952. On the relation between vegetation and electrolytes in north Swedish mire waters. Oikos 2:242-258.

Tantu, A. 1914. Über die entstehung der biilten und stränge der moore. Acta Forestalia Fennica 4:1-24.

Ter Braak, C. J. F. 1988. CANOCO: A FORTRAN program of Canonical, Community Ordination by (Partial) (Detrended) (Canonical) Correspondence Analysis, Principal Components and Redundancy Analysis (Version 2.1) Technical report LWA-88-02. Agricultural Mathematics Group, Wageninen, The Netherlands.
Ter Braak, C. J. F. 1991. Update notes: CANOCO Version 3.10. Agricultural Mathematics Group. Wageninen, The Netherlands.

Vitt, D. H., L. A. Halsey, and S. C. Zoltai. 1994. The bog landforms of continental western Canada, relative to climate and permafrost patterns. Arctic and Alpine Research 26:1-13.

Vitt, D. H., S. E. Bayley, and T.-L. Jin. 1995. Seasonal variation in water chemistry over a bog-rich fen gradient in continental westem Canada. Canadian Journal of Fisheries and Aquatic Sciences 52:587-606.

Vitt, D. H., L. A. Halsey, M. N. Thormann, and T. Martin. 1996. Peatland inventory of Alberta. Phase 1: Overview of peatland resources in the natural regions and subregions of the province. Peatland Resource Centre, Devonian Botanic Garden, University of Alberta, Edmonton, Alberta, Canada.

Veldhuis, H., R. E. Smith, G. F. Mills, R. G. Eilers, C. Selby, and M. Santry. 1996. Terrestrial ecozones, ecoregions, and ecodistricts of Manitoba: An ecological stratification of Manitoba's Natural Landscape. Manitoba Land Resource Unit, Centre for Land and Biological Resources Research, Research Branch, Agriculture Canada, draft version.

Zoltai, S. C. 1975. Southern limit of coniferous trees on the Canadian prairies. Canadian Forest Service Northern Forest Centre Information Report NOR-X-128.

Zoltai, S. C. and D. H. Vitt. 1990. Holocene climatic change and the distribution of peatlands in the western interior of Canada. Quaternary Research 33:231-240.

Zoltai, S. C. and D. H. Vitt. 1995. Canadian wetlands: environmental gradients and classification. Vegetatio 118:131-137.

Manuscript received 27 September 1996; revision received 28 February 1997; accepted 7 March 1997. 